\title{
A cerâmica cinzenta do estuário do Tejo durante a Idade do Ferro: algumas precisões sobre a sua cronologia, tipologia, produção e consumo
}

\section{The Tagus estuary Gray ware during the Iron Age: some details concerning its chronology, typology, production and consumption}

\author{
ELISA DE SOUSA \\ Universidade de Lisboa - Faculdade de Letras \\ Uniarq (Centro de Arqueologia) \\ e.sousa@campus.ul.pt \\ https://orcid.org/0000-0003-3160-108X
}

\section{Resumo}

O progressivo desenvolvimento de trabalhos arqueológicos no estuário do Tejo tem permitido conhecer, cada vez com mais detalhe, as características e a evolução de diversas componentes da cultura material da Idade do Ferro, entre as quais a cerâmica cinzenta. Apesar de ser uma categoria transversal a várias regiões da Península Ibérica, esta adquire, na zona da Baixa Estremadura, algumas características tipológicas e evolutivas singulares, que refletem especificidades regionais que devem ser valorizadas. Neste trabalho apresenta-se uma proposta de sistematização tipológica que integra agora todas as formas conhecidas de cerâmica cinzenta no Baixo Tejo, associando-as a parâmetros cronológicos mais bem definidos, e permitindo uma ulterior leitura de padrões de consumo destes produtos, em diferentes ambientes culturais, ao longo do $1^{\circ}$ milénio a. C.

Palavras-chave: $1^{\circ}$ milénio a. C., ocidente atlântico, cultura material, tipologia, padrões de consumo

\section{Abstract}

The development of archaeological fieldworks in the Tagus estuary enabled a better understanding of the evolution and characteristics of several components of the Iron Age material culture, which includes the so-called gray wares. Although these productions are common to several other Iberian regions, they acquired, in the Portuguese Estremadura, some unique characteristics, which reflect regional specificities that should be highlighted. In this work we present a proposal for the typological systematization, which now integrates all known forms of gray wares in the Lower Tagus, associating them with better defined chronological parameters, and allowing a further reading of the consumption patterns of these products, in different cultural environments, throughout the $1^{\text {st }}$ millennium B.C.

Key words: $1^{\text {st }}$ millennium BC, Western Atlantic, material culture, typology, consumption patterns 


\section{Introdução}

A cerâmica cinzenta da Idade do Ferro é uma das produções que tem sido estudada com mais detalhe no quadro dos estudos proto-históricos. Desde a sua primeira individualização, na década de 50 do século passado (Almagro Basch, I949), tornou-se, contudo, óbvio, que este conceito de «cerâmica cinzenta» engloba uma heterogénea multiplicidade de realidades culturais que abrangem grande parte $\mathrm{da}$ bacia do Mediterrâneo. Ainda assim, dentro desta diversidade, as produções ocidentais reúnem uma série de características comuns que permitem a sua individualização face a outros horizontes materiais.

O reconhecimento e, sobretudo, a vinculação desta categoria a ambientes ligados, directa ou indiretamente, aos cenários da colonização fenícia ocorreu a partir da década de I970, sendo múltiplos os estudos a ela dedicados. Não obstante, certos aspectos permanecem em ainda em discussão, sobretudo aqueles relacionados com a adscrição cultural da sua origem, que é entendida quer no quadro de ambientes fenício-ocidentais, quer em cenários da adopção de novas tecnologias de produção oleira pelas comunidades indígenas peninsulares que são, contudo, adaptadas às tradições pré-existentes (Roos, I982; González Prats, I983; Caro Bellido, I989; Mancebo, I994; Torres Ortiz, 2002; Vallejo Sánchez, 2005, 20II, 2015; Vives-Ferrándiz, 2005; Sanna, 2009; Groot, 20II). Mas independentemente da sua origem, a verdade é que a produção destes vasos, que se inicia durante o século viII a. C., decorreu simultaneamente em ambientes de natureza colonial, como se verifica no Cerro del Villar (Aubet et alii, I999) e em Cádis (Ramon Torres et alii, 2007), e em núcleos indígenas peninsulares (González Prats e Pina Gosalbez, I983; Lorrio, 2008; Vallejo Sánchez, 2015; Dorado, 20I9). E ainda que a tecnologia subjacente ao seu fabrico seja indubitavelmente de origem oriental, a selecção de determinados aspectos estéticos e formais dos recipientes reproduzidos parece indicar que a componente indígena ocidental teve uma marcada influência na concepção destas produções (Torres, 2002; Lorrio, 2008; Vallejo Sánchez, 20II, 20I5). Não obstante a discussão inerente à emergência destas produções cinzentas ocidentais, permanece inequívoco que elas são utilizadas, indiscriminadamente, por agentes fenícios, indígenas e comunidades hibridizadas, revelando a sua transversalidade.

A vasta dispersão destes vasos no território peninsular, que se estende deste o quadrante sudeste até à fachada central atlântica portuguesa, atingindo inclusivamente zonas interiores como a Extremadura espanhola, indica que a sua difusão foi, muito provavelmente, potenciada pela criação das redes de contacto do mundo fenício-ocidental, que encontraram nestes produtos uma resposta a certas demandas específicas por parte dos diferentes grupos indígenas (Roos, I992; Vives-Ferrándiz, 2005). Com efeito, as cerâmicas cinzentas foram rapidamente adoptadas em várias regiões do centro e sul da Península Ibérica, sendo reproduzidas em diferentes esferas culturais ao longo do $\mathrm{I}^{\mathrm{o}}$ milénio a. $\mathrm{C}$. Esta situação gerou, contudo, elencos morfológicos complexos, nos quais são visíveis certas tendências transversais, mas também claras variações regionais, como se manifesta nas múltiplas tipologias disponíveis para estas produções cinzentas (ver, entre outros, Roos, I982; Caro Bellido, I989; González Prats, I983; Ros Sala, I989; Mancebo, I994; Lorrio, 2008; Vallejo Sánchez, 20II, 20I5).

A cerâmica cinzenta do estuário do Tejo reflete, uma vez mais, esta complexidade, observando-se características formais partilhadas com outros horizontes regionais peninsulares, mas também especificidades singulares que devem ser assinaladas e sistematizadas, e que refletem, de certa forma, o percurso histórico desta área ao longo do $\mathrm{I}^{\mathrm{O}}$ milénio a. C.

\section{A cerâmica cinzenta no estuário do Tejo}

Os dados disponíveis indicam que as primeiras cerâmicas cinzentas aparecem, no estuário do Tejo, a partir do final do século viır a. C., em cronologia tradicional, sendo um reflexo de uma terceira ou quarta vaga da colonização fenícia no Ocidente, que chega, nesta altura, à fachada central da costa atlântica (Arruda, 1999-2000, 2005; Sousa, 2018).

Os agentes fenícios que então se instalam na Estremadura Portuguesa, e que são provavelmente 


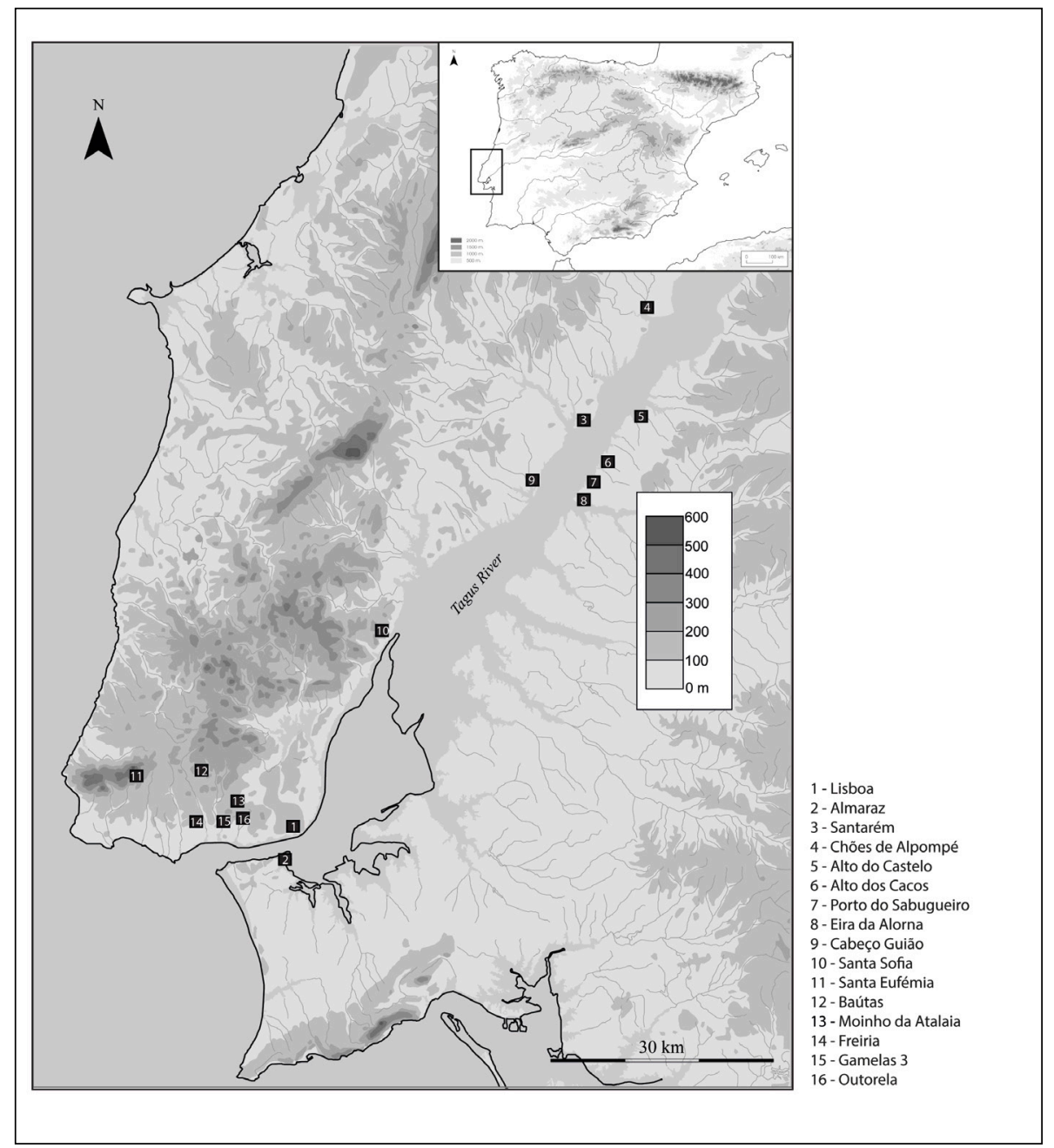

Figura 1. Mapa da área analisada, com localização dos sítios referidos ao longo do texto (base cartográfica de Rui Boaventura)

Figure 1. Map of the analyzed area, with location of the sites referred in the text (cartographic base by Rui Boaventura)

originários de núcleos andaluzes, trazem consigo um «pacote artefactual orientalizante» plenamente consolidado, e no qual a cerâmica cinzenta se encontra já presente. Assim, e pelo menos no caso específico do estuário do Tejo, a origem desta categoria está directamente vinculada ao processo da colonização fenícia, ainda que estas produções tenham sido também adoptadas, adaptadas e reproduzidas pelas próprias comunidades indígenas locais.

A irradiação da cerâmica cinzenta no estuário do Tejo ocorreu não só em ambientes de natureza provavelmente colonial, como é o caso do(s) núcleo(s) de Lisboa-Almaraz, localizado na foz do estuário (Arruda et alii, 200o; Henriques, 2006; Sousa, 20I6), mas também em outros mais interiores e de cariz marcadamente indígena, como é o caso da Alcáçova de Santarém (Arruda, I999-2000; Sousa e Arruda, 20I8) (figura I). E apesar de não se poder excluir categoricamente a eventual presença de vasos importados de regiões mais meridionais, é muito provável que a grande maioria da cerâmica cinzenta documentada na área do Tejo corresponda a produções locais/regionais, ainda que não tenha sido possível, até à data, identificar os respectivos centros oleiros. Estes, contudo, são provavelmente múltiplos e amplamente disseminados na região centro-atlântica, ainda que os fabricos detectados sejam bastante homogéneos. Com efeito, as produções de cerâmica cinzenta detectadas nesta região apresentam, na generalidade, pastas bem depuradas, sendo distinguível, macroscopicamente, a presença de calcites, quartzos, moscovites e, ocasionalmente, alguns nódulos ferruginosos 

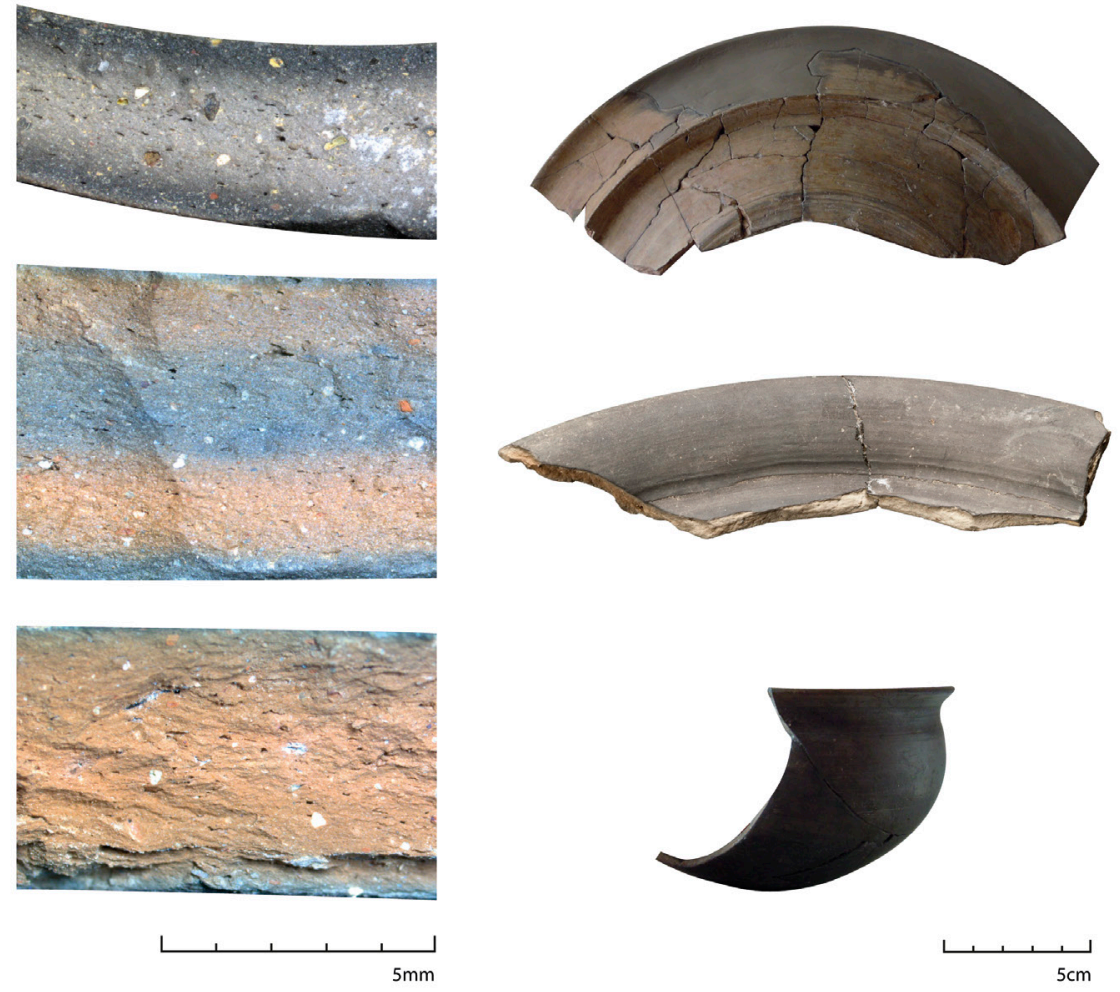

Figura 2. Produções de cerâmica cinzenta de Lisboa

Figure 2. Gray ware productions from Lisbon

(Sousa, 20I4: 13I). Uma maior variação observa-se apenas na tonalidade do seu interior das pastas, que pode ser de cor cinzenta ou alaranjada (ainda que por vezes com o núcleo escurecido) (figura 2).

$\mathrm{Na}$ zona do Baixo Tejo, assim como em outras áreas peninsulares (ver síntese recente em Vallejo Sánchez, 2015), a funcionalidade predominante dos vasos de cerâmica cinzenta foi o serviço de mesa, o que seguramente determinou o cuidado aplicado no seu acabamento, e que se reflete nas superfícies cuidadosamente polidas. Com efeito, só em casos mais excepcionais é que se verifica o uso de recipientes desta produção para outras funções, como é o caso do armazenamento de líquidos e alimentos.

É, contudo, bastante provável que os vasos de cerâmica cinzenta tenham sido também utilizados em outros ambientes, concretamente de natureza ritual e funerária, à semelhança do que ocorre em outras zonas da Península Ibérica. Infelizmente, o grande desconhecimento sobre este tipo de manifestações no registo arqueológico da Estremadura portuguesa não permite, de momento, explorar a sua função nestas esferas.
No que diz respeito à utilização de motivos decorativos na cerâmica cinzenta, a sua recorrência é relativamente rara no estuário do Tejo, assim como em outros ambientes peninsulares (Vallejo Sánchez, 2015: 8I-82). Quando se verifica a existência de decorações, estas são sobretudo brunidas (figura 3 a e c), recorrendo às mesmas técnicas disseminadas durante a fase final da Idade do Bronze. Em casos ainda mais excepcionais, pode verificar-se a utilização parcial de aguadas, engobes e bandas pintadas (figura $3 \mathrm{~g}$ ). A presença de motivos incisos é também rara, podendo destacar-se, a título de exemplo, a possível sequência de flores de lótus estilizadas recolhida na Alcáçova de Santarém (Sousa e Arruda, 2018), podendo acrescentar-se ainda a existência de algumas marcas anepígrafas, de produção ou de propriedade (figura 3 c, d e e).

\subsection{Quadro tipológico}

A vasta quantidade de dados actualmente disponíveis para as produções cinzentas do estuário do Tejo obriga a uma revisão do elenco tipológico regional. 


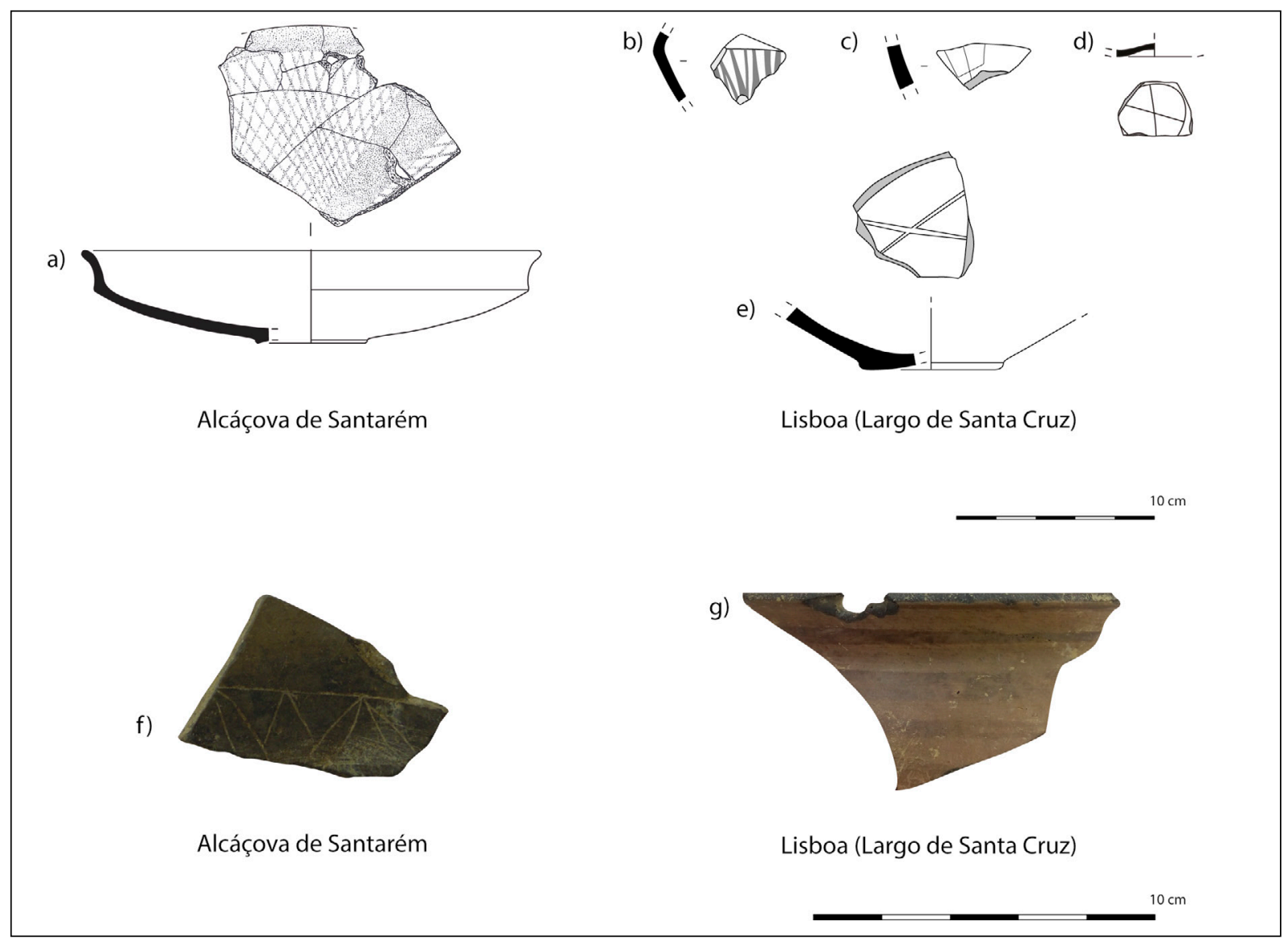

Figura 3. Alguns elementos decorativos das cerâmicas cinzentas do estuário do Tejo (dados recolhidos a partir de Arruda 1999-2000; Sousa e Arruda 2018; Sousa e Guerra 2018)

Figure 3. Some decorative elements of gray wares from the Tagus estuary (data collected from Arruda, 1999-2000; Sousa and Arruda, 2018; Sousa and Guerra, 2018)

Até à data, as propostas existentes foram elaboradas com base em conjuntos circunscritos e geralmente enquadráveis em fases cronológicas muito específicas (Arruda, 1999-2000; Arruda et alii, 2000; Henriques, 2006; Sousa, 2014), limitando uma análise mais transversal. Contudo, a recente publicação de informações contextuais de vários sítios ocupados durante a Idade do Ferro na Estremadura portuguesa, com momentos cronológicos bastante bem definidos, especialmente para as fases iniciais deste período, possibilitam agora ensaiar uma sistematização mais abrangente do repertório da cerâmica cinzenta nesta região e sua evolução ao longo do $\mathrm{I}^{\mathrm{O}}$ milénio a. C. Ainda assim, é importante precisar que as cronologias aqui propostas referem-se especificamente à realidade do Baixo Tejo, uma vez que formas idênticas ou semelhantes podem adquirir outros parâmetros temporais nos restantes contextos peninsulares (figura 4).
A base desta proposta de sistematização recai num esquema tipológico elaborado para a segunda metade do $\mathrm{I}^{\circ}$ milénio a. C. (Sousa, 20I4), que engloba já algumas das formas identificadas, e cujo carácter aberto permite a inclusão de novas morfologias. Esta opção permite manter as classificações que têm sido usadas recentemente para a caracterização de conjuntos de cerâmica cinzenta, mas também alargar o seu espetro de utilização, que passa agora a abranger a quase totalidade do repertório das cerâmicas cinzentas regionais da Idade do Ferro.

A sua estrutura segue os parâmetros originais (Sousa, 20I4), sendo a primeira divisão estabelecida (série) feita de acordo com aspectos funcionais primários, sendo os grupos, variantes e sub-variantes, definidos de acordo com critérios morfológicos progressivamente específicos. Sempre que possível, é apresentada a baliza cronológica de utilização de cada forma, ainda que esta deva assumir, em 


\begin{tabular}{|c|c|c|c|}
\hline Sítio & Contexto & Cronologia & Bibliografia \\
\hline Chões de Alpompé & $\begin{array}{l}\text { Enchimento de fossas [212] } \\
\text { e [214] }\end{array}$ & VII-VI a. C. & Arruda et alii, 2018 \\
\hline Chões de Alpompé & U.E. [209] / [206]/ [204] / [202] & IV-III a. C. & Arruda et alii, 2018 \\
\hline Alto do Castelo & Prospecção & VIIIIV/III a. C. & Arruda et alii, 2014 \\
\hline Santarém & Vários & VIII-III a. C. & Arruda, $1999-2000$ \\
\hline Santarém 2001 & Fase 1 & Fin. VIII-in. VII a. C. & Sousa e Arruda, 2018 \\
\hline Santarém 2001 & Fase 2 & $1^{\text {a }}$ metade VII a. C. & Sousa e Arruda, 2018 \\
\hline Santarém 2001 & Fase 3 & $2^{\mathrm{a}}$ metade VII a. $\mathrm{C}$. & Sousa e Arruda, 2018 \\
\hline Santarém 2001 & Fase 4 & $1^{\mathrm{a}}$ metade $\mathrm{VI}$ a. $\mathrm{C}$. & Sousa e Arruda, 2018 \\
\hline Santarém 2001 & Fase 5 & $2^{\text {a }}$ metade $\mathrm{VI}$ a. $\mathrm{C}$. & Sousa e Arruda, 2018 \\
\hline Santarém 2001 & Fase 6 & $2^{\mathrm{a}}$ metade/finais VI a. C. & Sousa e Arruda, 2018 \\
\hline Cabeço Guião & Vários & V-III a. C. & Arruda et alii, 2017 \\
\hline Alto dos Cacos & Prospecção & VIIIIIV/III a. C. & Sousa et alii, 2016/2017 \\
\hline Eira da Alorna & Prospecção & VII-V/IV a. C. & Pimenta et alii, 2018 \\
\hline Porto do Sabugueiro & Prospecção & VIIIIII a. C. & Rodrigues et alii, 2019 \\
\hline Santa Sofia & Vários & VIII-VII a. C. & Pimenta e Mendes, 2010/2011 \\
\hline Lisboa - Largo de Santa Cruz & Fase 1 & VII a. C. & Sousa e Guerra, 2018 \\
\hline Lisboa - Largo de Santa Cruz & Fase 2 & Último quartel VII a. C. & Sousa e Guerra, 2018 \\
\hline Lisboa - Largo de Santa Cruz & Fase 3 & $1^{\text {a }}$ metade VI a. C. & Sousa e Guerra, 2018 \\
\hline Lisboa - Largo de Santa Cruz & Fase 4 & $2^{\mathrm{a}}$ metade $\mathrm{VI}$ a. $\mathrm{C}$. & Sousa e Guerra, 2018 \\
\hline Lisboa - Largo de Santa Cruz & Fase 5 & va. C. & Sousa e Guerra, 2018 \\
\hline Lisboa - Sé & Vários & $2^{\text {a }}$ metade $\mathrm{VI}$ a. $\mathrm{C}$. & Arruda, 1999-2000 \\
\hline Lisboa - Pátio do Aljube & Vários & VII-VI a. C. & Fernandes et alii, 2013 \\
\hline Lisboa - Chafariz d’El Rei & Vários & VII-V/IV a. C. & Filipe et alii, 2014 \\
\hline Lisboa - Rua do Recolhimento & Vários & Fin. VIII-III a. C. & Sousa e Pinto, 2016 \\
\hline Lisboa - Rua dos Correeiros & Vários & V-in. IV a. C. & Sousa, 2014 \\
\hline Lisboa - Rua da Judiaria & Vários & VII-VI a. C. & Calado et alii, 2013 \\
\hline Lisboa - São João da Praça & Vários & $\begin{array}{l}\text { VII-V a. C. (materiais residuais) } \\
\text { e III a. C. (contextos) }\end{array}$ & Pimenta et alii, 2014b \\
\hline Moinho da Atalaia Oeste & Vários & V-IV/III a. C. & Sousa, 2014 \\
\hline Gamelas 3 & Vários & V-IV/III a. C. & Cardoso e Silva, 2013 \\
\hline Outorela I e II & Vários & V-IV/III a. C. & Cardoso et alii, 2014 \\
\hline Freiria & Vários & V-IV/III a. C. & Cardoso e Encarnação, 2013 \\
\hline Quinta do Almaraz & Vários & VIII a V/IV a. C. & $\begin{array}{l}\text { Barros e Henriques, 2002; } \\
\text { Henriques, 2006; Barros e } \\
\text { Batalha, } 2018\end{array}$ \\
\hline
\end{tabular}

Figura 4. Principais contextos arqueológicos para a definição da cronologia da cerâmica cinzenta da Estremadura Portuguesa

Figure 4. Main archaeological contexts for defining the chronology of gray wares in the Portuguese Estremadura

determinados casos, um carácter provisório, tendo de ser revista com ulteriores dados contextuais. De forma a estabelecer as bases de futuras análises comparativas no quadro peninsular, assinalamos, sempre que possível, equivalências com outros quadros tipológicos criados para a caracterização de outros focos produtivos de cerâmicas cinzentas. Cabe destacar, entre estes últimos, a recente proposta de Juan
Ignacio Vallejo Sánchez (2015), que se destaca por tentar abranger todas as realidades conhecidas no Ocidente. Apesar de ser uma proposta excepcional e francamente útil para identificar tendências mais gerais na evolução das cerâmicas cinzentas, coloca, de certa forma, em segundo plano, o carácter essencialmente regional que acaba por definir estas produções, enquadrando tipologias específicas de certas 
áreas em grupos muito abrangentes que acabam por perder, em parte, as particularidades inerentes à escala destas produções. No caso específico do estuário do Tejo, e apesar da transversalidade de algumas morfologias identificadas, a evolução deste horizonte cultural manifesta-se em rasgos tipológicos únicos, que devem ser valorizados devidamente no contexto regional. $\mathrm{O}$ «conservadorismo orientalizante» verificado nesta área (Arruda, 1999-2000) irá observar-se, justamente, na ampla perduração das cerâmicas cinzentas ao longo do $\mathrm{I}^{\mathrm{O}}$ milénio a. C., que atinge inclusivamente as últimas centúrias do $\mathrm{I}^{\mathrm{o}}$ milénio a. C., momento em que se verifica a emulação dos serviços de mesa itálicos, mas cujo conhecimento se encontra ainda numa fase incipiente.

\subsubsection{Série 1 (figuras 5 e 6)}

Designação comum: tigelas

Descrição: recipientes abertos e relativamente profundos

Funcionalidade: primariamente serviço de mesa (consumo de alimentos líquidos e semi-líquidos)

\section{Grupo 1A: tigelas de perfil simples}

Equivalências tipológicas: trata-se de formas transversais a praticamente todos os elencos tipológicos regionais, equivalendo a várias das variantes integradas por Vallejo Sánchez no seu grupo A.I.1 (2015). Pode estabelecer-se ainda uma correspondência geral com o tipo 20 de Caro (1989), com o tipo I A e I C de Mancebo (1994) e com o tipo A1 de Lorrio (2008). Cabe ainda referir que, na área do Tejo, esta morfologia foi designada como forma i na Alcáçova de Santarém (Arruda, I999-2000) e como tipo 1 da Sé de Lisboa (Arruda et alii, 200o).

\section{Variante $1 \mathrm{Aa}$}

Características: recipientes de perfil semi-hemisférico, com paredes arqueadas e côncavas. O bordo é simples e contínuo, sendo a sua secção variável, podendo ser indistinto da restante parede, engrossado internamente e, mais raramente, apresentar uma ranhura na zona superior, como se verifica em exemplares recolhidos na Quinta do Almaraz (Henriques, 2006: 122, n. ${ }^{\circ} 3$ a 5). $\mathrm{O}$ fundo parece ser sobretudo convexo, podendo ter uma curvatura mais ou menos acentuada, apresentando, em algumas ocasiões, um pé assinalado.

A única sub-variante assinalada neste grupo,1Aa.1, distingue-se por apresentar um bordo assinalado no exterior, característica que aparece sobretudo a partir dos meados do I $^{\mathrm{o}}$ milénio a. C.

Cronologia: desde o final do século viII até ao século III a. C. (com eventuais perdurações até ao período romano).

Dimensões: diâmetro do bordo muito variável, podendo ir desde os 136 até aos $250 \mathrm{~mm}$. Nota-se, contudo, uma maior incidência nos diâmetros entre os I70-180 mm e $210-220 \mathrm{~mm}$. O diâmetro dos fundos oscila entre os 50 e os $58 \mathrm{~mm}$, e a altura destes recipientes entre os 50 e os $80 \mathrm{~mm}$.

\section{Variante $1 \mathrm{Ab}$}

Características: recipientes semelhantes aos anteriores, distinguindo-se pelas suas paredes rectilíneas, que conferem a estas peças um perfil mais troncocónico. O bordo pode ser simples e contínuo ou engrossado na área interna. $O$ fundo mantém as mesmas características assinaladas na variante anterior.

Também neste caso foi possível documentar alguns exemplares que se distinguem pela presença de um bordo assinalado exteriormente, tendo-se utilizado, neste caso, a designação de sub-variante $1 \mathrm{Ab} .1$, que surge, uma vez mais, sobretudo a partir dos meados do I ${ }^{\mathrm{o}}$ milénio a. C.

Cronologia: desde o século vi a. C. até ao século III a. C. (com eventuais perdurações até ao período romano).

Dimensões: o diâmetro do bordo pode oscilar entre os 136 e os $244 \mathrm{~mm}$, notando-se uma maior concentração entre os 210 e $220 \mathrm{~mm}$. O diâmetro do fundo varia entre os 42 e os $60 \mathrm{~mm}$ e a altura entre os 40 e $66 \mathrm{~mm}$.

\section{Grupo 1B: tigelas de perfil carenado}

Equivalências tipológicas: tal como ocorre no caso anterior, esta morfologia é transversal a várias áreas da Península Ibérica. Ainda assim, os exemplares da área do Tejo da variante $1 \mathrm{Ba}$ aproximam-se, sobretudo, das variantes A.II.3 (particularmente da variante c) 
de Vallejo Sánchez (2015). Pode estabelecer-se ainda uma correspondência geral com os tipos 17 a 19 de Caro (1989), com o tipo II C de Mancebo (r994) e com o tipo A2 de Lorrio (2008). Para a variante $1 \mathrm{Bb}$, os melhores paralelos encontram-se no tipo A.II.4 de Vallejo Sánchez (2015), particularmente nas variantes a e b.

\section{Variante $1 \mathrm{Ba}$}

Características: a forma geral destes recipientes não é muito distinta do grupo anterior, com a excepção da presença de uma carena, suave e alta, que não tem, contudo, repercussões significativas no perfil interno. O bordo é curto, ligeiramente evertido, e assinalado no exterior, apresentando uma secção circular. Os dois exemplares de perfil completo que se integram nesta foram são provenientes da Quinta do Almaraz (Barros e Henriques, 2002), exibindo um fundo aplanado. Contudo, numa destas peças, o diâmetro de base é muito reduzido, o que dificilmente permitiria uma boa estabilidade do recipiente, pelo que se pode considerar, pelo menos neste caso, uma utilização paralela como tampa.

Cronologia: dados contextuais seguros indicam a sua utilização entre o século v e o início do século Iv a. C., ainda que seja muito provável que tenha balizas cronológicas mais amplas, considerando outros paralelos do território peninsular.

Dimensões: diâmetro do bordo entre I48 e $220 \mathrm{~mm}$. O diâmetro dos fundos oscila entre os 26 e $45 \mathrm{~mm}$, e a altura entre $4 \mathrm{I}$ e $45 \mathrm{~mm}$.

\section{Variante $1 \mathrm{Bb}$}

Características: esta segunda variante caracteriza-se por uma maior profundidade, assim como pela presença de uma carena mais vincada. O bordo é simples e evertido, sendo a base ligeiramente convexa. Apenas um exemplar da área do Baixo Tejo integra esta morfologia, tendo sido recuperado na Quinta do Almaraz (Barros e Henriques, 2002).

Cronologia: ainda que a cronologia resultante das escavações realizadas na Quinta do Almaraz não permita balizas muito específicas, é provável que esta morfologia se enquadre, sobretudo, nos momentos mais antigos da Idade do Ferro.

Dimensões: diâmetro do bordo de $280 \mathrm{~mm}$, diâmetro de fundo de $60 \mathrm{~mm}$ e altura de $105 \mathrm{~mm}$.
Grupo 1C: tigelas menos profundas, com a zona superior vertical ou reentrante

Equivalências tipológicas: em termos gerais, é possível estabelecer alguns paralelismos com exemplares da variante A.I.1.E de Vallejo Sánchez (20I5), ainda que os perfis em questão não tenham uma correspondência exacta nos exemplares taganos. Pode estabelecer-se ainda uma correspondência geral com o tipo I B de Mancebo (1994), sendo também necessário referir que exemplares semelhantes foram integrados no tipo I (sobretudo variante B) da Sé de Lisboa (Arruda et alii, 2000).

\section{Variante 1Ca}

Características: mantendo o perfil geral semi-hemisférico, os recipientes integrados nesta variante apresentam uma profundidade mais reduzida quando comparada com os casos anteriores. O bordo é também distinto, apresentando uma orientação mais vertical e até reentrante. A sua secção é circular, podendo ser engrossado na área interna.

Cronologia: século vir a. C. até ao início do século Iv a. C., ainda que seja provável que a sua utilização possa ser mais prolongada.

Dimensões: diâmetro do bordo entre 138 e $216 \mathrm{~mm}$.

Grupo 1D: tigelas de perfil canelado, marcado por sulcos e/ou saliências mais ou menos acentuadas ao longo do corpo da peça

Equivalências tipológicas: ainda que não se tenham identificado paralelos directos, cabe referir que perfis canelados em formas abertas foram agrupados por Vallejo Sánchez (2015) no seu tipo A.I.1.b., que reúne peças recuperadas na área de Málaga e, já no território português, em Abul B (Mayet e Silva, 200o). Deve, contudo, também assinalar-se algumas semelhanças com um dos exemplares integrado no tipo A.II.1.d de Vallejo Sánchez (2015: fig. 6.I7 n. ${ }^{\circ} 4$ ).

\section{Variante 1Da}

Características: recipientes de perfil geral semi-hemisférico, com bordo simples e contínuo, podendo apresentar algum espessamento, sendo de secção sub-circular ou biselado.

Cronologia: século v a III a. C.

Dimensões: diâmetro do bordo entre 216 e $280 \mathrm{~mm}$. 


\section{Série 1}

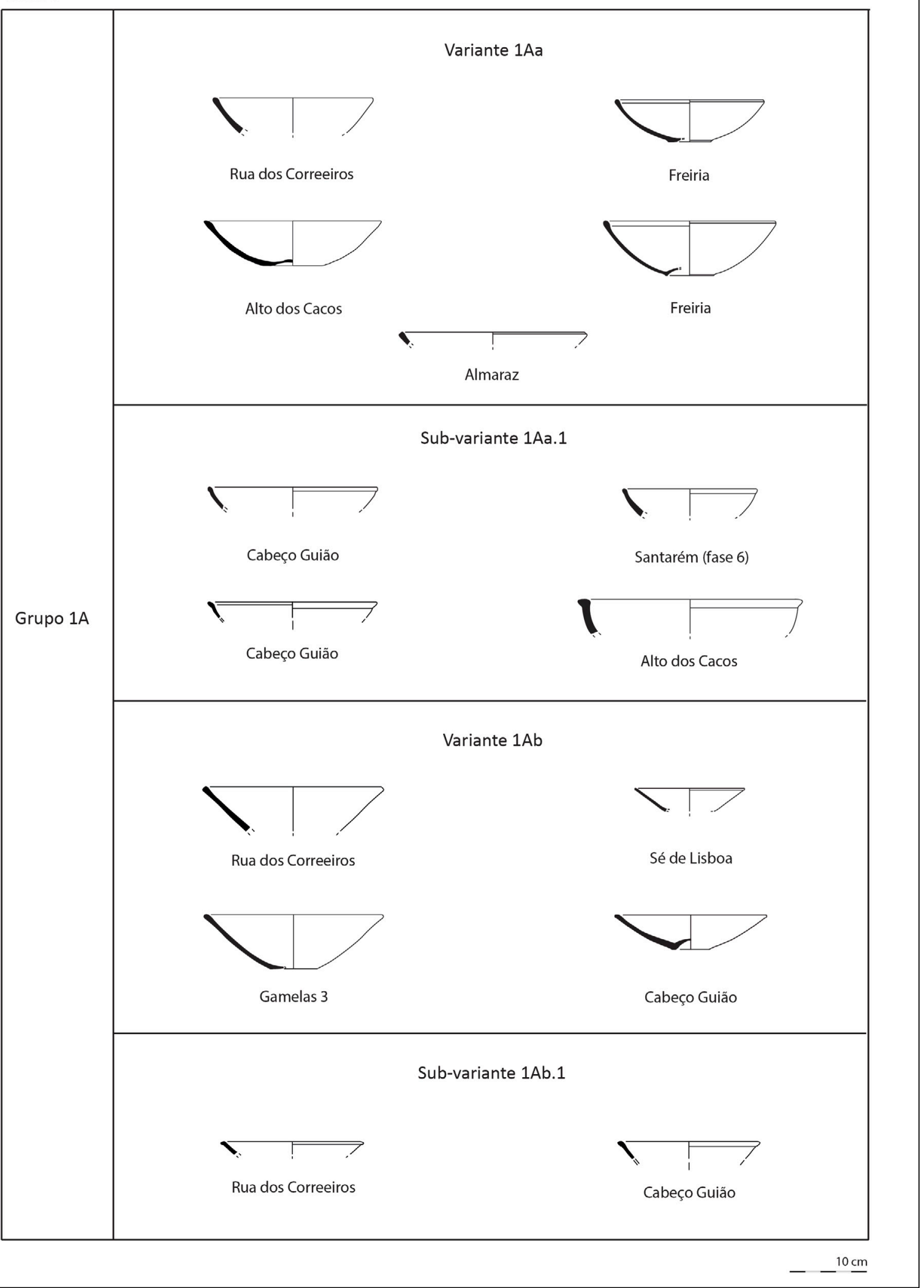

Figura 5. Série 1 do estuário do Tejo (dados recolhidos a partir de Arruda et alii, 2000, 2017; Cardoso e Encarnação, 2013; Cardoso e Silva, 2013; Henriques, 2006; Sousa, 2014; Sousa e Arruda, 2018; Sousa et alii, 2016-2017)

Figure 5. Series 1 of the Tagus estuary (data collected from Arruda et al., 2000, 2017; Cardoso and Encarnação, 2013; Cardoso and Silva, 2013; Henriques, 2006; Sousa, 2014; Sousa and Arruda, 2018; Sousa et al., 2016-2017) 
Variante 1Db

Características: idêntica à anterior, sendo o bordo mais evertido.

Cronologia: século v a III a. C.

Dimensões: diâmetro do bordo de $270 \mathrm{~mm}$.

\subsubsection{Série 2 (figuras 7 e 8)}

Designação comum: tigelas / pratos

Descrição: recipientes mais abertos e menos profundos

Funcionalidade: primariamente serviço de mesa (consumo de alimentos sólidos e talvez também semi-líquidos)

Grupo 2A: tigela/prato de perfil carenado e paredes tendencialmente horizontais que se desenvolvem a partir da zona inferior da carena

Equivalências tipológicas: trata-se uma morfologia particularmente frequente na zona mais ocidental da Península Ibérica. Com efeito, alguns dos exemplares da variante $2 \mathrm{Ab}$ do Tejo encontram os seus melhores paralelos no tipo A.II.1 (variante d) de Vallejo Sánchez, que integra, sobretudo, exemplares da área portuguesa (Abul B - Mayet e Silva, 2000; Santarém - Arruda, I999-2000). No caso da variante $2 \mathrm{Ac}$ do Tejo, detectam-se ainda similitudes com o grupo A.II.2.d de Vallejo Sánchez (2015). Pode estabelecer-se ainda uma correspondência geral com o tipo 17-B de Caro (I989), com o tipo II D (I) de Mancebo (I994) e mesmo com o tipo C 2 de Lorrio (2008), ainda que os exemplares taganos não tenham o perfil completamente determinado.

\section{Variante $2 \mathrm{Aa}$}

Características: os recipientes desta variante caracterizam-se pela tendência vertical da parte superior da peça. O bordo é simples e contínuo, de secção sub-circular, e ligeiramente oblíquo.

Cronologia: contextualmente associado a níveis desde o século $\mathrm{v}$ até ao início do século iv a. C., sendo possível que a sua utilização se tenha prolongado no tempo.

Dimensões: diâmetro do bordo entre 156 e I66 mm.
Variante $2 \mathrm{Ab}$

Características: recipientes de dimensões superiores aos da variante anterior, apresentando a zona superior mais oblíqua e a carena mais bem marcada. O bordo é também mais evertido, mantendo a secção sub-circular. Cronologia: seguramente entre o século v a III a. C., mas é possível que o seu período de utilização seja mais amplo.

Dimensões: diâmetro do bordo entre 230 e $340 \mathrm{~mm}$.

\section{Variante 2Ac}

Características: recipientes com carena mais alta e zona superior menos desenvolvida. O bordo é evertido, podendo em algumas ocasiões ser aplanado. Trata-se de uma morfologia que apresenta muitas semelhanças com outras formas documentadas em cerâmica de engobe vermelho e cerâmica comum que são normalmente designadas de páteras (Sousa, 20I4), sendo possível que a zona central da peça pudesse apresentar uma concavidade acentuada, a partir da qual se seguiria um pé desenvolvido. Será, contudo, necessário esperar pela identificação de perfis mais bem conservados destas produções de cerâmica cinzenta para confirmar esta associação.

Cronologia: século v a III a. C.

Dimensões: diâmetro do bordo entre 200 e $352 \mathrm{~mm}$.

Grupo 2B: tigela/prato de perfil carenado e paredes oblíquas

Equivalências tipológicas: esta morfologia foi englobada por Vallejo Sánchez (2015) no tipo A.II.1.d. Cabe ainda destacar, em termos gerais, algumas similitudes com o tipo C4 de Lorrio (2008).

\section{Variante 2Ba}

Características: recipientes mais profundos que os anteriores. A carena encontra-se muito bem marcada, chegando a formar uma saliência na zona exterior e uma concavidade interna. $\mathrm{O}$ bordo é evertido e geralmente aplanado. Alguns dos exemplares mais bem conservados evidenciam um pé alto e desenvolvido, ainda que num caso, em Gamelas 3, o fundo pareça ser apenas convexo (Cardoso e Silva, 20I3: 372). Cronologia: século v a III a. C.

Dimensões: diâmetro do bordo muito coerente, entre os 280 e os $300 \mathrm{~mm}$. O diâmetro de fundo é de $76 \mathrm{~mm}$, e a altura de $74 \mathrm{~mm}$. 


\section{Série 1}

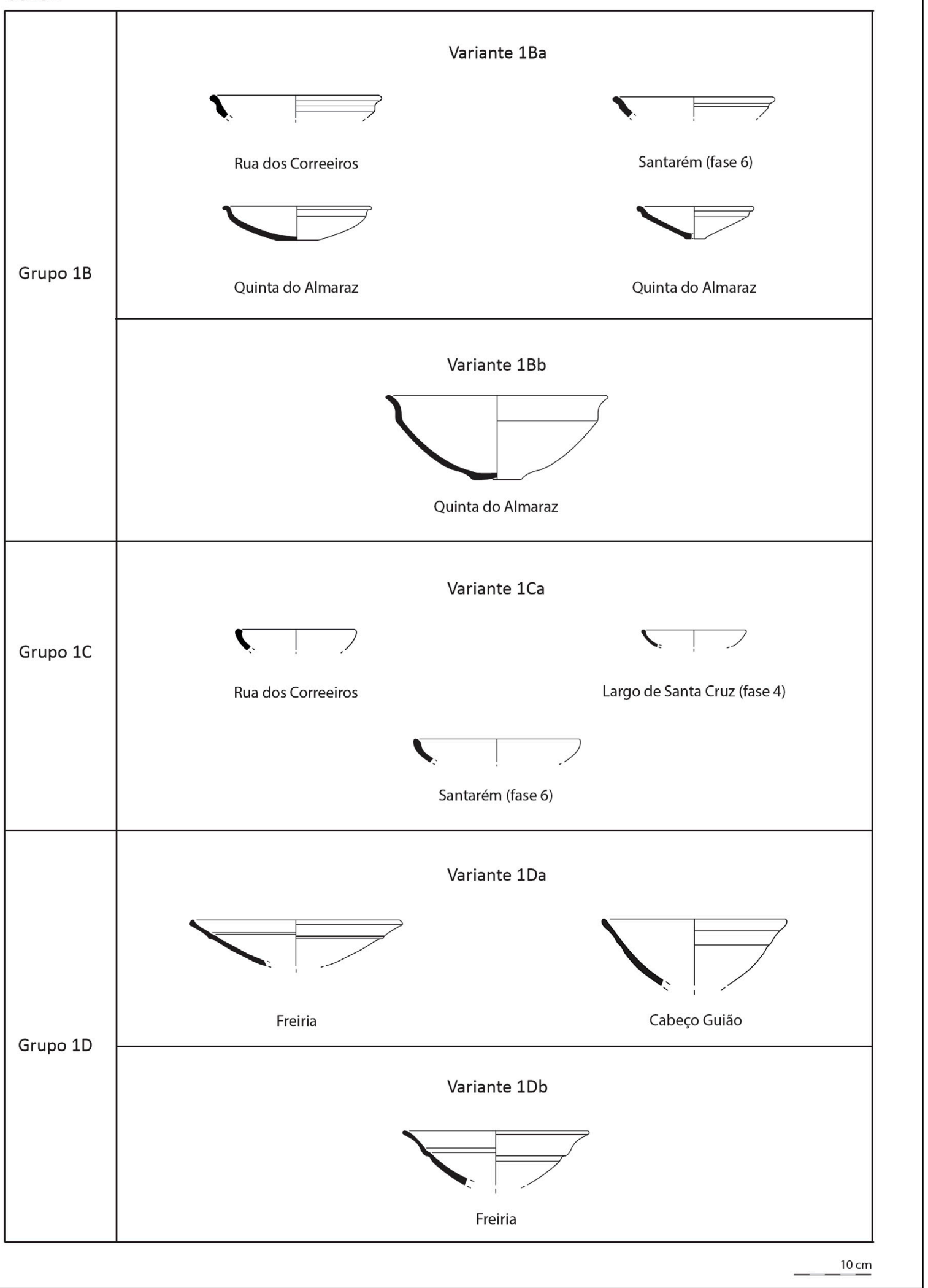

Figura 6. Série 1 do estuário do Tejo (dados recolhidos a partir de Arruda et alii, 2017; Barros e Henriques, 2002; Cardoso e Encarnação, 2013; Sousa, 2014; Sousa e Arruda, 2018; Sousa e Guerra, 2018)

Figure 6. Series 1 of the Tagus estuary (data collected from Arruda et al., 2017; Barros and Henriques, 2002; Cardoso and Encarnação, 2013; Sousa, 2014; Sousa and Arruda, 2018; Sousa and Guerra, 2018) 
Série 2

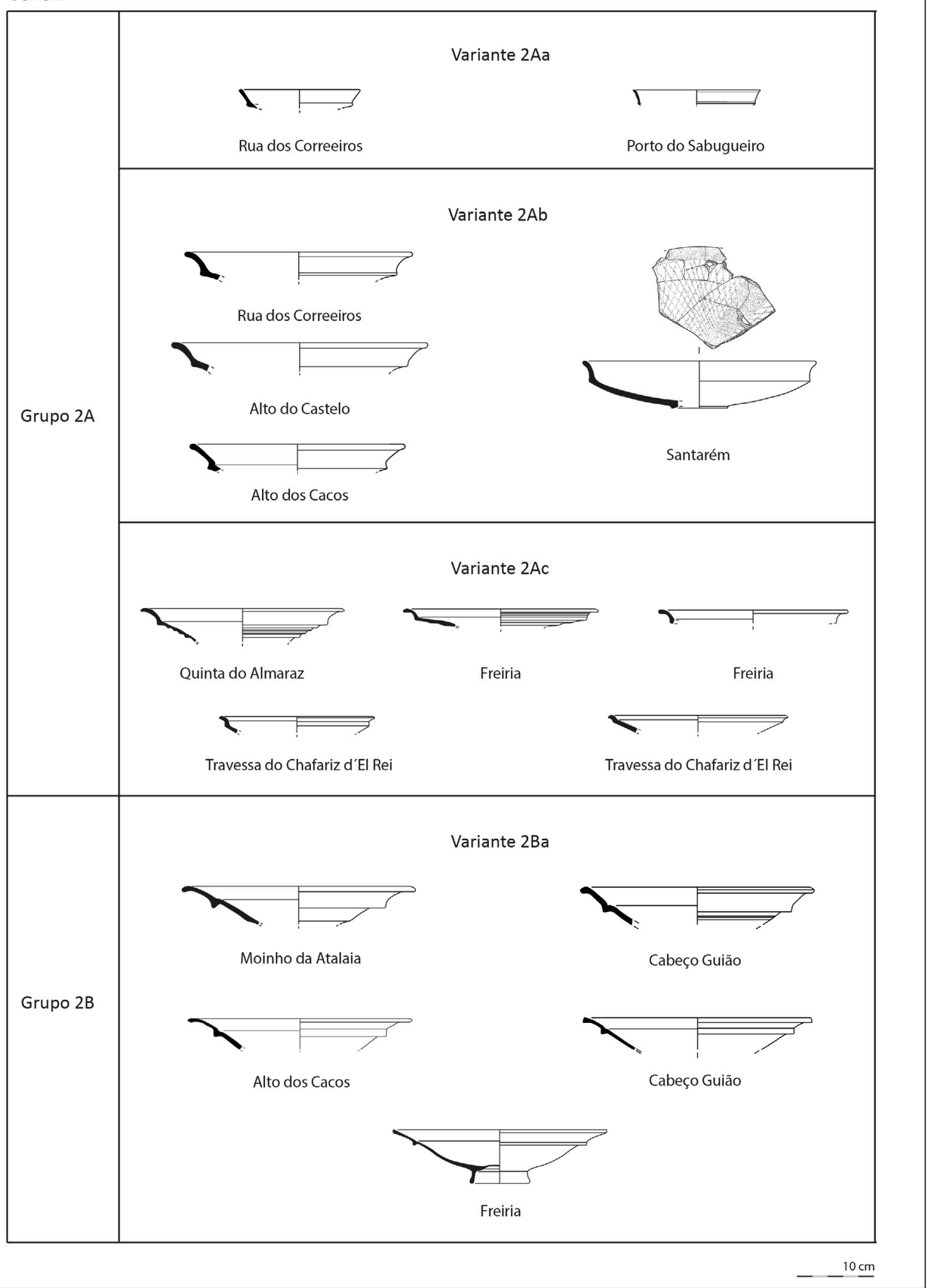

Figura 7. Série 2 do estuário do Tejo (dados recolhidos a partir de Arruda, 1999-2000; Arruda et alii, 2014, 2017; Barros e Batalha, 2018; Cardoso e Encarnação, 2013; Filipe et alii, 2014; Rodrigues et alii, 2019; Sousa, 2014; Sousa et alii, 2016-2017)

Figure 7. Series 2 of the Tagus estuary (data collected from Arruda, 1999-2000; Arruda et al., 2014, 2017; Barros and Batalha, 2018; Cardoso and Encarnação, 2013; Filipe et al., 2014; Rodrigues et al., 2019; Sousa, 2014; Sousa et al., 2016-2017) 
Grupo 2C: prato de perfil simples

Equivalências tipológicas: em termos gerais, pode-se assinalar algumas semelhanças com o tipo IIA e IIF de Mancebo (I994) e com o tipo A III de Lorrio (2008). Na área do Tejo, esta morfologia foi designada como forma 2 A na Alcáçova de Santarém (Arruda, I999-2000) e como tipo 2 da Sé de Lisboa (Arruda et alii, 2000).

\section{Variante $2 \mathrm{Ca}$}

Características: recipientes pouco profundos, com paredes de tendência oblíqua. O bordo é simples e contínuo, de secção sub-circular, e praticamente indiferenciável da parede, assinalando-se apenas uma ligeira distinção do lábio na zona interna. Trata-se, muito provavelmente, de reproduções de cerâmica cinzenta das tipologias de pratos de engobe vermelho e de cerâmica comum.

Cronologia: século vir e vi a. C.

Dimensões: diâmetro do bordo oscila entre os I98 e os $222 \mathrm{~mm}$.

\section{Variante $2 \mathrm{Cb}$}

Características: recipientes praticamente idênticos aos anteriores, diferenciando-se apenas por apresentar um pequeno lábio assinalado na zona exterior, e por terem dimensões algo superiores.

Cronologia: até ao momento, a única cronologia disponível para estes exemplares é a segunda metade do século vi a. C., não sendo, contudo, impossível que possam ter uma origem mais antiga.

Dimensões: diâmetro do bordo entre 270 a $280 \mathrm{~mm}$.

\section{Variante 2Cc}

Características: os recipientes englobados nesta variante distinguem-se dos anteriores por apresentarem um lábio mais desenvolvido e aplanado, de secção sub-circular. A distinção entre o lábio e a restante parede é também muito mais acentuada do que na primeira variante deste grupo. Trata-se, uma vez mais, de formas inspiradas nas produções de cerâmica de engobe vermelho e de cerâmica comum. Cronologia: final do século viı//início do viı a. C. até à segunda metade do século vi a. C.

Dimensões: com a excepção de um caso, documentado da Sé de Lisboa (Arruda et alii, 2000: fig. 8 n. ${ }^{\circ}$ 9), que tem um diâmetro de apenas $150 \mathrm{~mm}$, a amplitude destes pratos varia entre os 218 e os $320 \mathrm{~mm}$.

\subsubsection{Série 3 (figuras 9, 10, 11 e 12)}

Designação comum: pequenos potes / taças

Descrição: recipientes profundos, de pequena ou média dimensão

Funcionalidade: primariamente serviço de mesa (consumo de líquidos)

Grupo 3A: pequenos potes de perfil carenado Equivalências tipológicas: uma das variantes do Tejo (3Aa) foi integrada no tipo B.II.2.b de Vallejo Sánchez (2015). Cabe ainda referir a equivalência entre a variante $3 A$ c e alguns exemplares do tipo 4 da Sé de Lisboa (Arruda et alii, 200o), que, por sua vez, se assemelham ao tipo C.II.6.a de Vallejo Sánchez (20I5).

\section{Variante 3Aa}

Características: os recipientes integrados nesta variante exibem um corpo de tendência ovalada, tendo a carena bem marcada na zona mesial. O bordo é simples, evertido e de secção sub-circular. O colo é desenvolvido, podendo apresentar uma ou mais saliências. Os exemplares mais bem conservados desta variante exibem um fundo convexo, podendo ter inclusivamente um pé destacado.

Cronologia: final do século vi (?) / século v a. C. a III a. C.

Dimensões: o diâmetro do bordo varia entre os $80 \mathrm{e}$ $150 \mathrm{~mm}$, notando-se uma maior incidência entre os IIo e os I2O mm. O diâmetro do fundo oscila entre os $33 \mathrm{~mm}$ e $42 \mathrm{~mm}$, e a altura entre os $90 \mathrm{~mm}$ e $\mathrm{I} 20 \mathrm{~mm}$.

\section{Variante $3 A b$}

Características: os recipientes desta variante distinguem-se por apresentarem um colo mais curto e anguloso, sendo o restante perfil semelhante ao caso anterior. Cronologia: o único exemplar identificado desta forma, proveniente do Porto do Sabugueiro (Rodrigues et alii, 20I9), não dispõe de informação contextual. Contudo, é possível que se enquadre dentro dos parâmetros cronológicos das restantes variantes deste grupo.

Dimensões: diâmetro do bordo de $84 \mathrm{~mm}$. 
Série 2

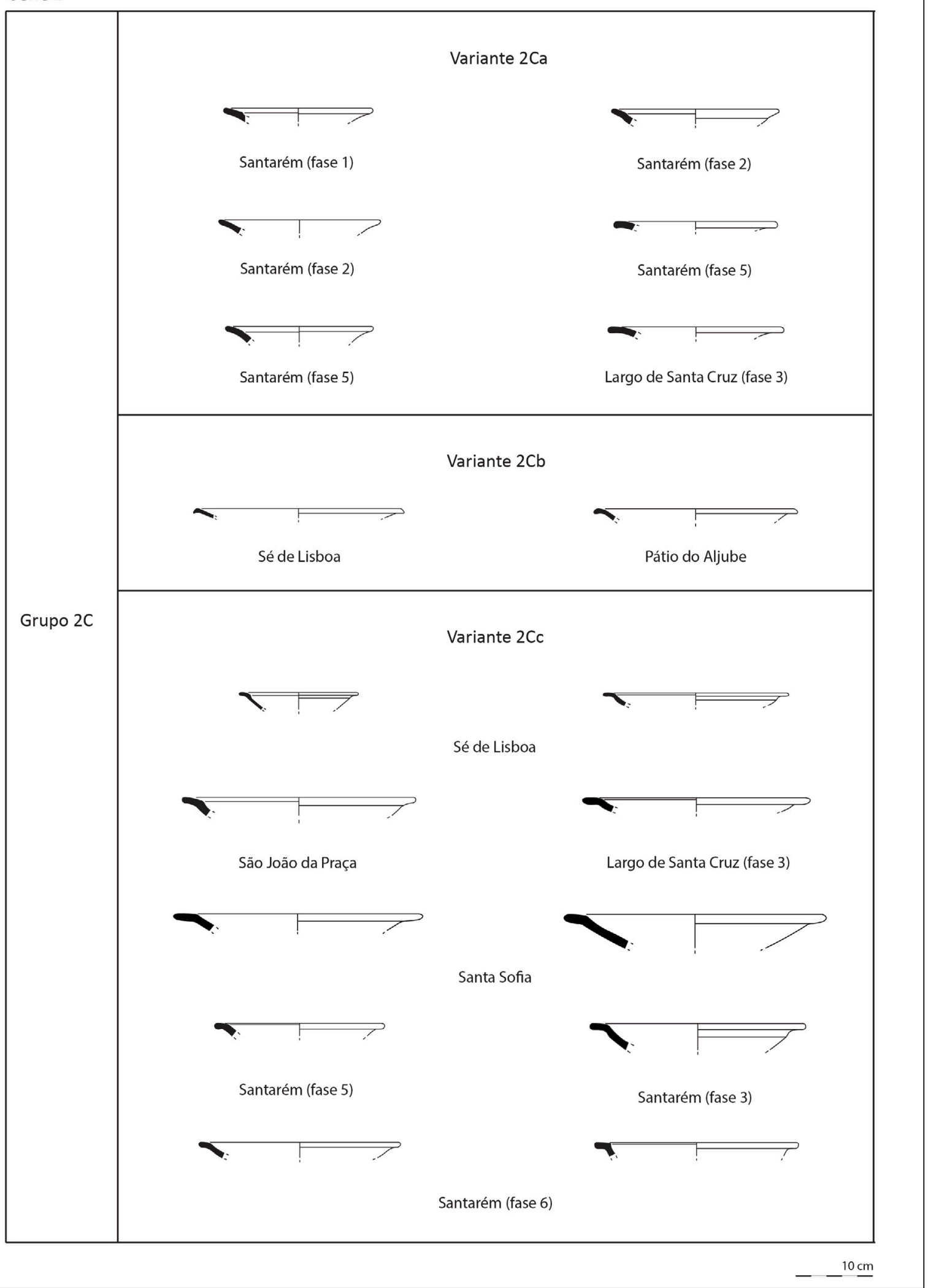

Figura 8. Série 2 do estuário do Tejo (dados recolhidos a partir de Arruda et alii, 2000; Fernandes et alii, 2013; Pimenta e Mendes 2010-2011; Pimenta et alii, 2014b; Sousa e Arruda, 2018; Sousa e Guerra, 2018)

Figure 8. Series 2 of the Tagus estuary (data collected from Arruda et al., 2000; Fernandes et al., 2013; Pimenta and Mendes, 2010-2011; Pimenta et al., 2014b; Sousa and Arruda, 2018; Sousa and Guerra, 2018) 
Variante 3Ac

Características: os recipientes desta variante caracterizam-se por apresentarem corpos aparentemente mais estreitos, sendo ainda difícil de determinar, atendendo à elevada fragmentação destas peças, se existem diferenças substanciais na zona inferior.

Cronologia: final do século vi a. C. até ao século iv / iII (?) a. C.

Dimensões: o diâmetro do bordo varia entre os $90 \mathrm{~mm}$ e os $\mathrm{I} 20 \mathrm{~mm}$.

Grupo 3B: pequenos potes de perfil elipsoidal Equivalências tipológicas: apresenta algumas similitudes com o tipo C.II.4.b de Vallejo Sánchez (2015), ainda que o perfil do corpo seja, aparentemente, um pouco distinto.

\section{Variante 3Ba}

Características: recipientes de corpo mais elipsoidal, com colo desenvolvido e de tendência cilíndrica. O bordo é simples e contínuo, podendo ser de tendência evertida. Os exemplares mais bem conservados exibem um fundo convexo, com pé destacado.

Cronologia: final do século vi a. C. até ao século iv / inI (?) a. C.

Dimensões: o diâmetro do bordo varia entre os 78 e $158 \mathrm{~mm}$, notando-se uma maior incidência entre os IIo e os $120 \mathrm{~mm}$. O único exemplar conservado tem um diâmetro de fundo de $48 \mathrm{~mm}$ e uma altura estimada de III mm.

Grupo 3C: pequenos potes de perfil rectilíneo e corpo estreito

Equivalências tipológicas: não foi possível estabelecer paralelismos com outras morfologias.

\section{Variante $3 \mathrm{Ca}$}

Características: recipientes com paredes mais estreitas e de tendência vertical, com uma carena na zona superior, a partir da qual se desenvolve um colo rectilíneo. O bordo, vertical ou ligeiramente reentrante, é indiferenciável da restante parede, sendo de secção sub-circular.

Cronologia: século v a III a. C.

Dimensões: diâmetro do bordo varia entre os 68 e os $80 \mathrm{~mm}$.
Grupo 3D: pequenos potes de perfil globular

Equivalências tipológicas: sendo uma das morfologias mais típicas da área do Tejo, equivale ao tipo 4 da Alcáçova de Santarém (Arruda, I999-2000) e ao tipo $3 \mathrm{~A}$ da Sé de Lisboa (Arruda et alii, 2000). A variante 3Da assemelha-se ainda ao tipo C.II.4. (sobretudo às variantes a e c) de Vallejo Sánchez (2015), e a variante $3 \mathrm{Db}$ do Tejo ao seu tipo B.II.3.c., sendo que grande parte destes exemplares foram recolhidos justamente na região portuguesa.

\section{Variante 3Da}

Características: recipientes de corpo globular, estando bem marcada a separação do bordo. Este é curto e vertical ou ligeiramente evertido, sendo de secção sub-circular.

Cronologia: segunda metade do século vi a. C.

Dimensões: diâmetro do bordo entre os 80 e os I26 $\mathrm{mm}$.

\section{Variante 3Db}

Características: distingue-se da anterior apenas pelas suas dimensões, superiores às dos casos precedentes.

Cronologia: segunda metade do século vi a. C.

Dimensões: diâmetro do bordo de $172 \mathrm{~mm}$.

\section{Grupo 3E: pequenas taças de perfil ovalado}

Equivalências tipológicas: apresenta semelhanças com o tipo A.II.5 de Vallejo Sánchez (2015), que integra um dos vasos recolhidos na Sé de Lisboa (Arruda et alii, 2000), mas também com outras variantes estabelecidas pelo investigador espanhol (A.IV.3.c, B.II.3.3, C.II.4.d). Na zona do Tejo, esta morfologia corresponde a exemplares incluídos no tipo 3 e 5 da Sé de Lisboa (Arruda et alii, 200o) e ainda ao tipo $4 \mathrm{~A}$ e 7 da Alcáçova de Santarém (Arruda, I999-2000).

\section{Variante 3Ea}

Características: recipientes abertos, com corpo tendencialmente ovalado. O bordo é curto, evertido, simples e de secção sub-circular, estando a sua separação do resto da peça bem marcada. $O$ fundo dos exemplares mais bem conservados é aplanado.

Cronologia: a maioria dos exemplares conhecidos enquadra-se em cronologias do século viI e vi a. C. 


\section{Série 3}

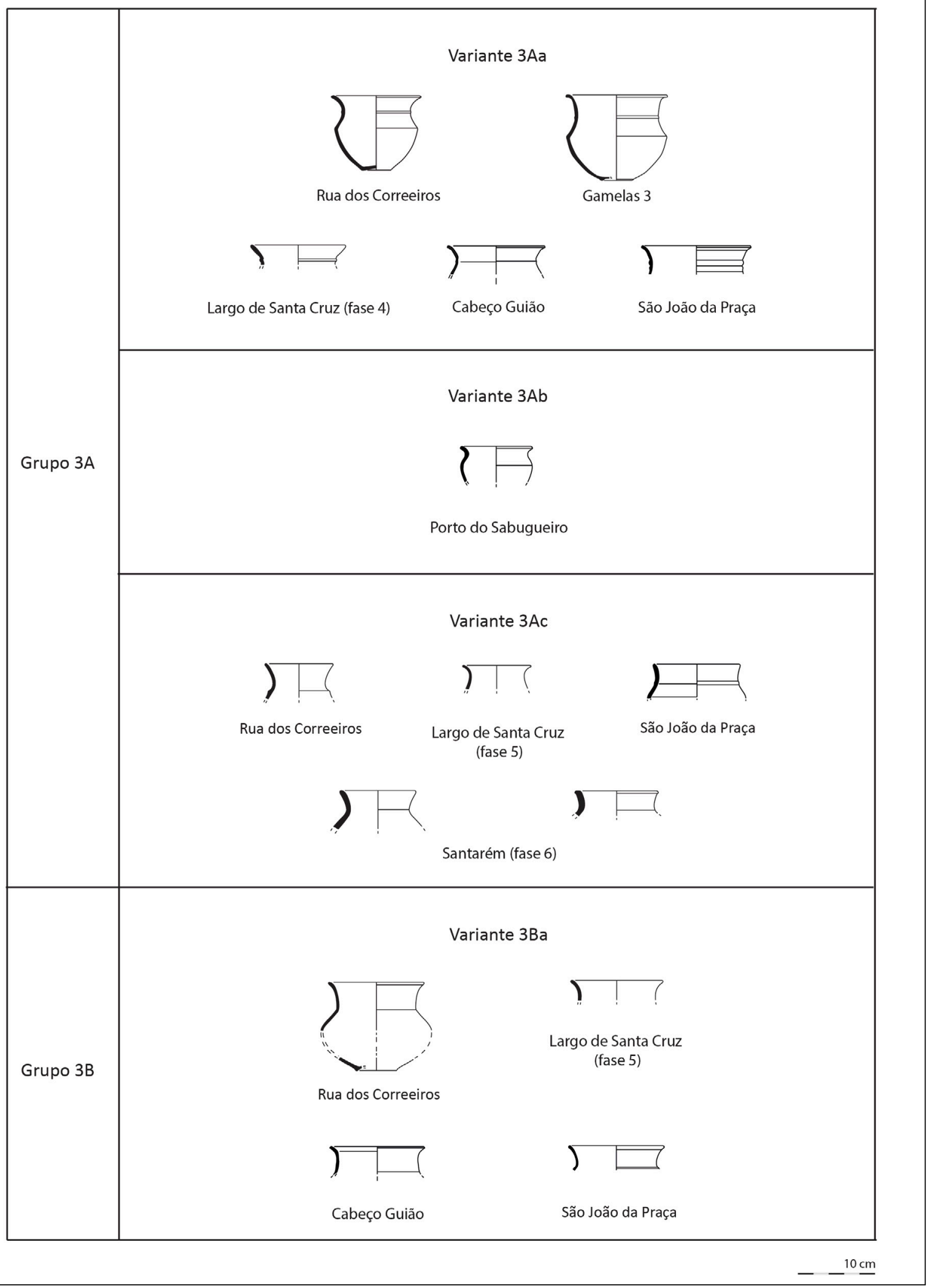

Figura 9. Série 3 do estuário do Tejo (dados recolhidos a partir de Arruda et alii, 2017; Cardoso e Silva, 2013; Pimenta et alii, 2014b; Rodrigues et alii, 2019; Sousa, 2014; Sousa e Arruda, 2018; Sousa e Guerra, 2018)

Figure 9. Series 3 of the Tagus estuary (data collected from Arruda et al., 2017; Cardoso and Silva, 2013; Pimenta et al., 2014b; Rodrigues et al., 2019; Sousa, 2014; Sousa and Arruda, 2018; Sousa and Guerra, 2018) 


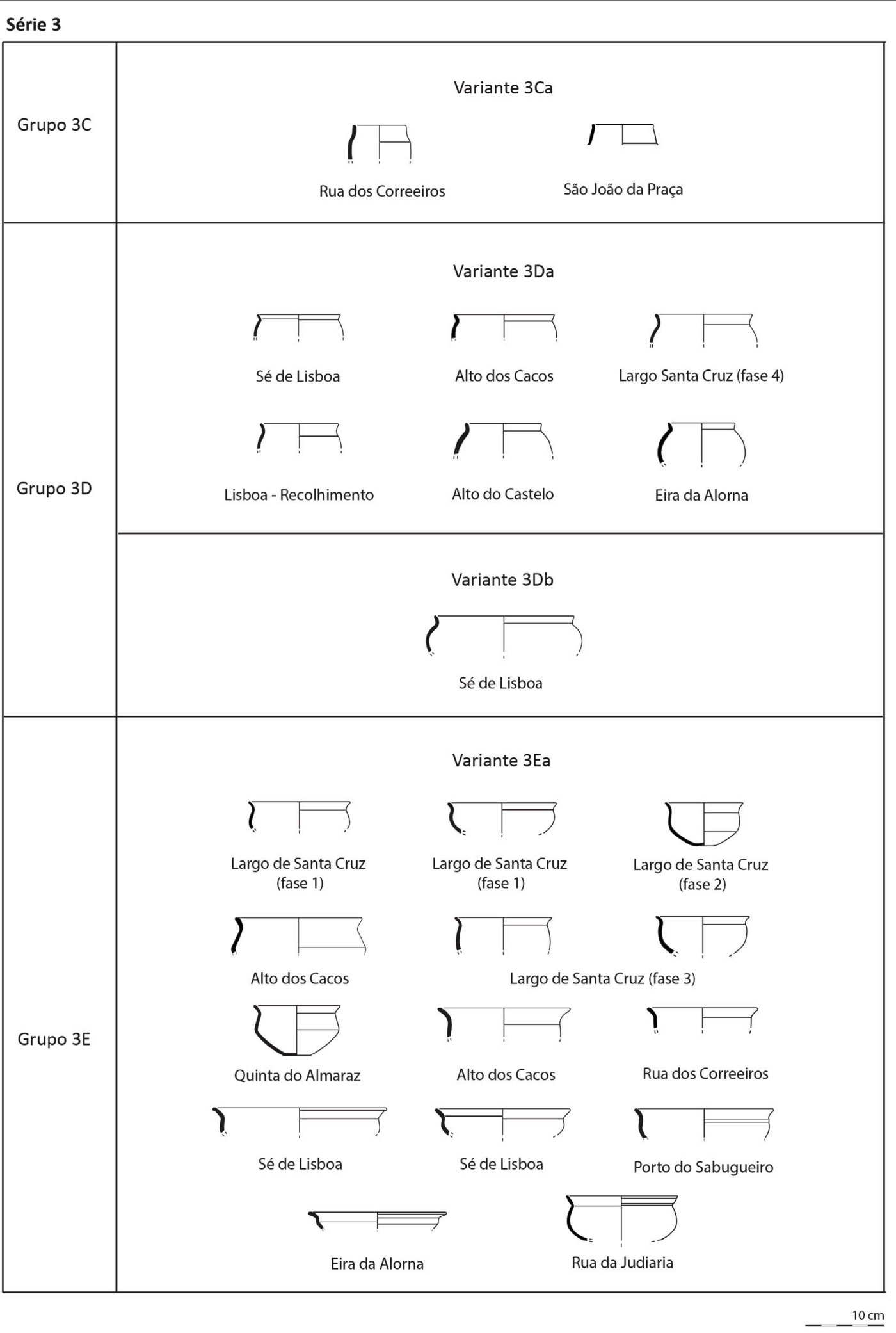

Figura 10. Série 3 do estuário do Tejo (dados recolhidos a partir de Arruda et alii, 2000, 2014; Barros e Henriques, 2002; Calado et alii, 2013; Pimenta et alii, 2014b, 2018; Rodrigues et alii, 2019; Sousa, 2014; Sousa e Guerra, 2018; Sousa e Pinto, 2016; Sousa et alii, 2016-2017)

Figure 10. Series 3 of the Tagus estuary (data collected from Arruda et al., 2000, 2014; Barros and Henriques, 2002; Calado et al., 2013; Pimenta et al., 2014b, 2018; Rodrigues et al., 2019; Sousa, 2014; Sousa and Guerra, 2018; Sousa and Pinto, 2016; Sousa et al., 2016-2017) 
Contudo, algumas peças recolhidas na Rua dos Correeiros (Sousa, 20I4: Est. 8, n. ${ }^{\circ} \mathrm{SN} \mathrm{A}_{3}$ e Est. I5, n. ${ }^{\circ}$ 2530) e Moinho da Atalaia Oeste (Sousa, 20I4: Est. 59 , n. ${ }^{\circ} 47 / 276 / 20 \mathrm{~B}$ e $8 /{ }_{3} / / 15 \mathrm{C}$ ) podem indicar que esta morfologia esteve em uso, ainda que de forma já residual, até ao século v/início do século Iv a. C. Dimensões: o diâmetro do bordo geralmente varia entre os Ioo e os $180 \mathrm{~mm}$, existindo dois casos com dimensões superiores, entre os 210 e os $250 \mathrm{~mm}$ (Arruda et alii, 2000: fig. II, n. ${ }^{\circ}$ 8; Pimenta et alii, 20I8: fig. 29, n. ${ }^{\circ}$ I2O). Os exemplares de perfil completo, recolhidos em Lisboa (Sousa e Guerra, 2018) e Almaraz (Barros e Henriques, 2002) têm diâmetros de fundo entre os $24 \mathrm{~mm}$ e $46 \mathrm{~mm}$ e uma altura entre 56 e $92 \mathrm{~mm}$.

\section{Grupo 3F: pequenas taças de perfil carenado}

Equivalências tipológicas: estas taças de dimensões reduzidas, que parecem reproduzir modelos $\mathrm{da}$ fase final da Idade do Bronze, são relativamente recorrentes nos repertórios da Península Ibérica, ainda que os seus perfis sejam bastante variáveis. É possível estabelecer algumas equivalências para as diferentes variantes individualizadas no estuário do Tejo: a variante $3 \mathrm{Fa}$ enquadra-se na forma $5 \mathrm{~B}$ da Alcáçova de Santarém (Arruda, 1999-2000), sendo ainda semelhante ao tipo A.IV.1, e a uma peça do tipo A.IV.4 de Vallejo Sánchez (20I5); a variante 3Fb e 3Fc correspondem à forma 5 A de Santarém (Arruda, 1999-2000), sendo também equiparáveis ao tipo A.I.3 de Vallejo Sánchez (20I5), ainda que a cronologia dos exemplares taganos seja anterior; a variante $3 \mathrm{Fd}$ equivale ao tipo 6 da Sé de Lisboa (Arruda et alii, 2000), sendo também semelhante a alguns exemplares integrados nos tipos A.IV.4 e A.IV.6 de Vallejo Sánchez (2015); a variante $3 \mathrm{Fe}$ tem semelhanças com o tipo A.IV.3.d e A.IV.3.b de Vallejo Sánchez (2015), que, por sua vez, enquadra a forma 3 da Alcáçova de Santarém (Arruda, I999-2000); a variante $3 \mathrm{Ff}$ assemelha-se aos tipo A.I.2 e A.II.4.c-1 de Vallejo Sánchez (20I5); para as últimas duas variantes (3Fg e 3Fh), não foi possível identificar paralelos claros.

\section{Variante $3 \mathrm{Fa}$}

Características: taças de carena baixa, pouco marcada. O bordo, de tendência vertical ou oblíqua, é simples, contínuo e de secção sub-circular.
Cronologia: final do século viII até ao século vi a. C. Dimensões: o diâmetro do bordo oscila entre os IIo e os $130 \mathrm{~mm}$.

\section{Variante $3 \mathrm{Fb}$}

Características: distingue-se da variante anterior pela tendência mais vertical das paredes e por apresentar o bordo assinalado na área externa, sendo este curto e evertido.

Cronologia: final do século viII até ao século vi a. C. Dimensões: o diâmetro do bordo oscila entre os Io6 e os I3o mm, com a excepção de um exemplar documentado nos Chões de Alpompé, que tem $172 \mathrm{~mm}$ de amplitude (Arruda et alii, 2018: fig. 13, n. ${ }^{\circ} 23$ ).

\section{Variante 3Fc}

Características: taças semelhantes às anteriores, mas com paredes tendencialmente mais oblíquas. O bordo é, com frequência, assinalado na zona exterior podendo inclusivamente ser aplanado.

Cronologia: final do século viII até ao século vi a. C. Dimensões: o diâmetro do bordo oscila entre os II6 e os $148 \mathrm{~mm}$.

\section{Variante $3 \mathrm{Fd}$}

Características: taças de perfil acampanado, sendo a parte superior curvilínea, terminando num bordo de secção sub-circular. A carena está localizada na zona inferior, sendo bem assinalada, parecendo dar início a um perfil mais globular.

Cronologia: meados do século vi até ao século IV/ III a. C.

Dimensões: o diâmetro do bordo oscila entre os 80 e os $126 \mathrm{~mm}$.

\section{Variante $3 \mathrm{Fe}$}

Características: taça de carena média. A parte superior é curvilínea, terminado num bordo de secção sub-circular. A carena está bem marcada, quer na zona interna quer na externa. Trata-se de uma morfologia que recorda em muito os protótipos de cerâmica manual da região do Tejo, que remontam ao Bronze Final.

Cronologia: o único exemplar desta forma, identificado na Alcáçova de Santarém (Sousa e Arruda, 20I8), foi recolhido num nível datado do século vir a. C.

Dimensões: diâmetro do bordo de $140 \mathrm{~mm}$. 


\section{Variante 3Ff}

Características: taça de carena alta, mas pouco assinalada. A zona superior é curta, terminando num bordo simples, ligeiramente evertido e de secção sub-circular. Tal como foi referido para o caso anterior, esta morfologia recorda em muito as taças carenadas do Bronze Final, e cuja perduração durante os momentos iniciais da Idade do Ferro se encontra bem documentada na Alcáçova de Santarém (Arruda, r999-2000; Sousa e Arruda, 2018).

Cronologia: século viI e vi a. C.

Dimensões: o diâmetro do bordo oscila entre os I30 e os I6o $\mathrm{mm}$.

\section{Variante 3Fg}

Características: taças de perfil semi-hemisférico, exibindo uma carena relativamente acentuada na zona interna. $O$ bordo é evertido, podendo apresentar uma secção sub-circular ou apontada.

Cronologia: século vi a. C.

Dimensões: o diâmetro do bordo oscila entre os Ioo e os $\mathrm{i} 76 \mathrm{~mm}$.

\section{Variante 3Fh}

Características: taças de perfil também semi-hemisférico, que se distinguem das variantes anteriores pela presença de um bordo aplanado e de secção sub-circular.

Cronologia: o único exemplar documentado até ao momento foi recuperado num nível datado da segunda metade do século vir a. C. (Sousa e Arruda, 20I8: fig. I8, n. ${ }^{\circ}$ 20I).

Dimensões: o diâmetro do bordo é de $136 \mathrm{~mm}$.

Grupo 3G: taças de influência helenística, observável sobretudo pela presença de asas horizontais

Equivalências tipológicas: não foi possível estabelecer paralelismos com outras morfologias.

\section{Variante $3 G a$}

Características: taça de carena média e bordo evertido, de secção sub-circular. As asas horizontais, de secção tendencialmente circular, arrancam da carena. O fundo apresenta um pé desenvolvido, de base convexa.
Cronologia: final do século IV (?)/ século III até ao século II a. C.

Dimensões: o diâmetro do bordo oscila entre os 94 e os I22 mm. O único exemplar de perfil completo, tem um diâmetro de fundo de $38 \mathrm{~mm}$ e uma altura de $60 \mathrm{~mm}$ (Arruda, Viegas e Almeida, 2002).

\section{Variante $3 \mathrm{~Gb}$}

Características: esta variante distingue-se da anterior unicamente por ter um corpo mais alto e estreito, assim como um fundo mais maciço. Trata-se de um exemplar que foi recuperado num nível de época romano-republicana (Pimenta et alii, 20I4a), sendo muito provavelmente uma evolução das taças anteriores.

Cronologia: o único exemplar conhecido foi recolhido num nível da segunda metade do século II a. C., não sendo, contudo, impossível que a sua origem possa remontar ainda aos momentos finais da Idade do Ferro.

Dimensões: o diâmetro do bordo é de $86 \mathrm{~mm}$, o de fundo de $60 \mathrm{~mm}$ e a altura é de rog $\mathrm{mm}$ (Pimenta et alii, 2014a).

\subsubsection{Série 4 (figuras 13, 14 e 15)}

Designação comum: potes

Descrição: recipientes fechados

Funcionalidade: primariamente armazenamento

Grupo 4A: pote de perfil em S

Equivalências tipológicas: em termos gerais, pode-se estabelecer uma equivalência com os tipos C.II.1 e C.II.5 de Vallejo Sánchez (2015), com o tipo 7 de Caro (I989), com o tipo VIII de Mancebo (I994) e com o tipo D1 A e D3 A de Lorrio (2008).

\section{Variante $4 \mathrm{Aa}$}

Características: recipientes de bordo evertido, com colo desenvolvido e de perfil cilíndrico, podendo, em algumas ocasiões, apresentar algum estrangulamento. $\mathrm{O}$ bordo é simples e contínuo, sendo praticamente indiferenciável da restante parede, e apresenta uma secção sub-circular. Trata-se de vasos que são, morfologicamente, muito difíceis de distinguir dos 
Série 3

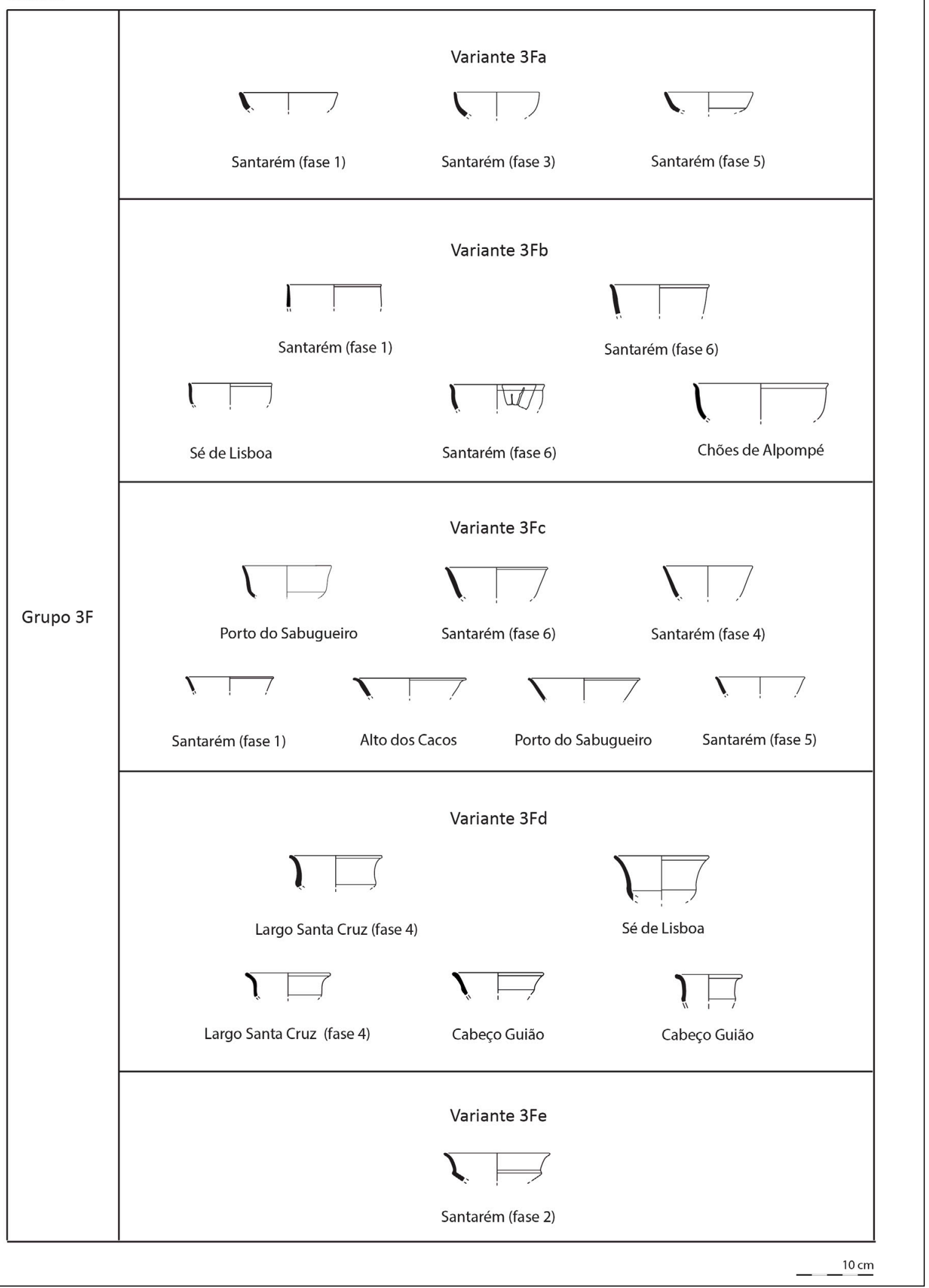

Figura 11. Série 3 do estuário do Tejo (dados recolhidos a partir de Arruda et alii, 2000, 2018; Rodrigues et alii, 2019; Sousa e Arruda, 2018; Sousa e Guerra, 2018; Sousa et alii, 2016-2017)

Figure 11. Series 3 of the Tagus estuary (data collected from Arruda et al., 2000, 2018; Rodrigues et al., 2019; Sousa and Arruda, 2018; Sousa and Guerra, 2018; Sousa et al., 2016-2017) 


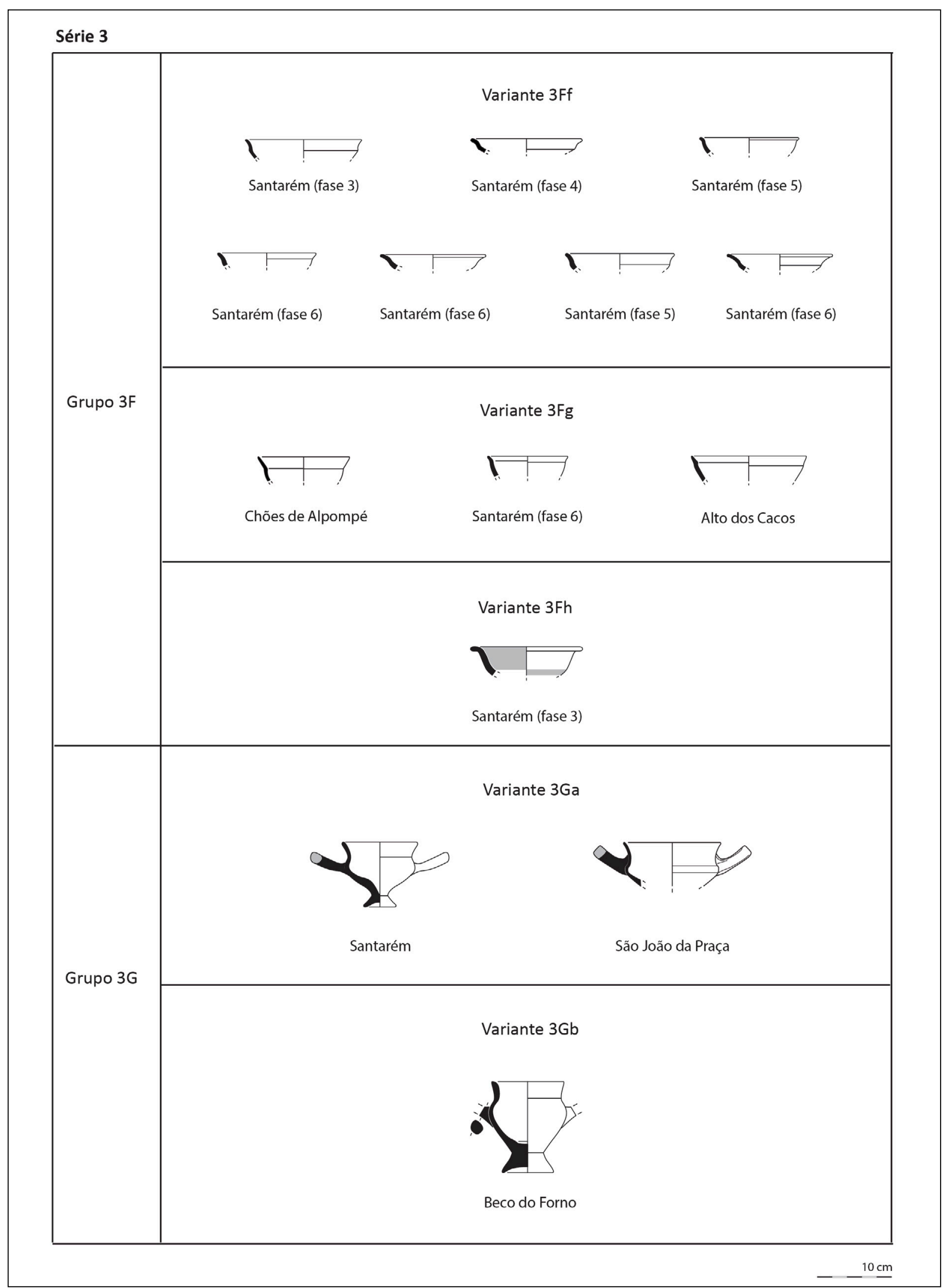

Figura 12. Série 3 do estuário do Tejo (dados recolhidos a partir de Arruda et alii, 2002, 2018; Pimenta et alii, 2014a e 2014b; Sousa e Arruda, 2018; Sousa et alii, 2016-2017)

Figure 12. Series 3 of the Tagus estuary (data collected from Arruda et al., 2002, 2018; Pimenta et al., 2014a and 2014b; Sousa and Arruda, 2018; Sousa et al., 2016-2017) 
pequenos potes dos grupos $3 \mathrm{~A}$ e $3 \mathrm{~B}$. Contudo, apresentam amplitudes de bordo de dimensões superiores, que sugerem uma funcionalidade distinta (já não orientada para o consumo de líquidos mas sim para utilização como vasos de armazenamento). Ainda que estejamos plenamente conscientes da dificuldade e subjectividade da determinação de um valor concreto para esta diferenciação, é possível propor que valores acima dos $160 \mathrm{~mm}$ seriam já integráveis no grupo dos vasos de armazenamento. No entanto, é verdade que para os recipientes que apresentam valores intermédios (entre os I40 e os I6o mm), é praticamente impossível assegurar a sua classificação, na ausência de perfis mais bem conservados. As sub-variantes assinaladas neste grupo são definidas pela presença de asas de secção circular. No primeiro caso (sub-variante 4Aa.1), as duas asas são externas e arrancam da zona do bordo. No segundo caso (sub-variante 4Aa.2), a asa é interna, passando por cima da abertura do vaso.

Cronologia: século vi a. C. a século iv/III a. C.

Dimensões: o diâmetro do bordo oscila entre os I40/160 e os I80 mm, documentando-se ainda um exemplar mais atípico, na Rua dos Correeiros, com $300 \mathrm{~mm}$ de amplitude (Sousa, 2014).

\section{Variante 4Ab}

Características: recipientes semelhantes aos anteriores, distinguindo-se apenas por um bordo mais vertical, estando a sua separação face ao restante corpo bem vincada.

Cronologia: século v a início do século Iv a. C.

Dimensões: o diâmetro do bordo é de $160 \mathrm{~mm}$.

\section{Variante 4Ac}

Características: recipientes semelhantes aos da variante $4 \mathrm{Aa}$, mas distinguíveis pela presença de um colo mais curto e estrangulado, podendo este estar marcado por uma saliência. O bordo é evertido e de secção sub-circular.

Cronologia: o único fragmento recuperado num contexto conservado sugere uma cronologia entre o século v e início do século iv a. C., sendo, contudo, provável que esta baliza seja mais alargada.

Dimensões: o diâmetro do bordo oscila entre os I 40 e os $200 \mathrm{~mm}$.

\section{Grupo 4B: potes de colo alto}

Equivalências tipológicas: em termos gerais,é possível estabelecer paralelismos entre a variante $4 \mathrm{Ba}$ do Tejo e alguns exemplares integrados por Vallejo Sánchez (2015) no tipo C.II.5; a variante $4 \mathrm{Bb}$, que equivale ao tipo 5 A da Alcáçova de Santarém (Arruda, I999-2000), foi integrada no tipo C.II.3-b do investigador espanhol.

\section{Variante 4Ba}

Características: recipientes com colo mais alto e de perfil mais cilíndrico. O bordo, de secção sub-circular, é evertido e por vezes aplanado. Um dos exemplares mais bem conservados, recolhido na Rua dos Correeiros (Sousa, 20I4), exibe uma carena acentuada na zona inferior.

Cronologia: século vi a Iv/III a. C.

Dimensões: o diâmetro do bordo oscila entre os I6o e os $210 \mathrm{~mm}$.

\section{Variante 4Bb}

Características: distingue-se da variante anterior pelo bordo, que é apenas assinalado exteriormente, e pelo perfil vertical do colo. O único exemplar desta forma foi documentado na Alcáçova de Santarém (Arruda, 1999-2000).

Cronologia: sobretudo momentos mais antigos da Idade do Ferro, possivelmente da primeira metade do I ${ }^{\circ}$ milénio a. C. (Arruda, I999-2000: 20I).

Dimensões: diâmetro do bordo de $240 \mathrm{~mm}$.

Grupo 4C: potes de colo estrangulado (evolução e/ou emulação dos vasos de tipo pithoi)

Equivalências tipológicas: vasos com morfologias semelhantes foram enquadrados por Vallejo Sánchez no tipo C.II.2 (20I5). Em termos gerais, é similar ao tipo 8 de Caro (1989), ao tipo X de Mancebo (1994) e ao tipo D2 de Lorrio (2008).

\section{Variante $4 \mathrm{Ca}$}

Características: recipientes com colo tendencialmente mais curto, mas mais estrangulado. $\mathrm{O}$ bordo apresenta algum espessamento, sendo geralmente de secção sub-circular ou sub-triangular.

Foi possível identificar uma sub-variante (4Ca.1), pela presença de duas asas externas, de secção ovalada. Cronologia: século vi a iv/III a. C. 
Série 4

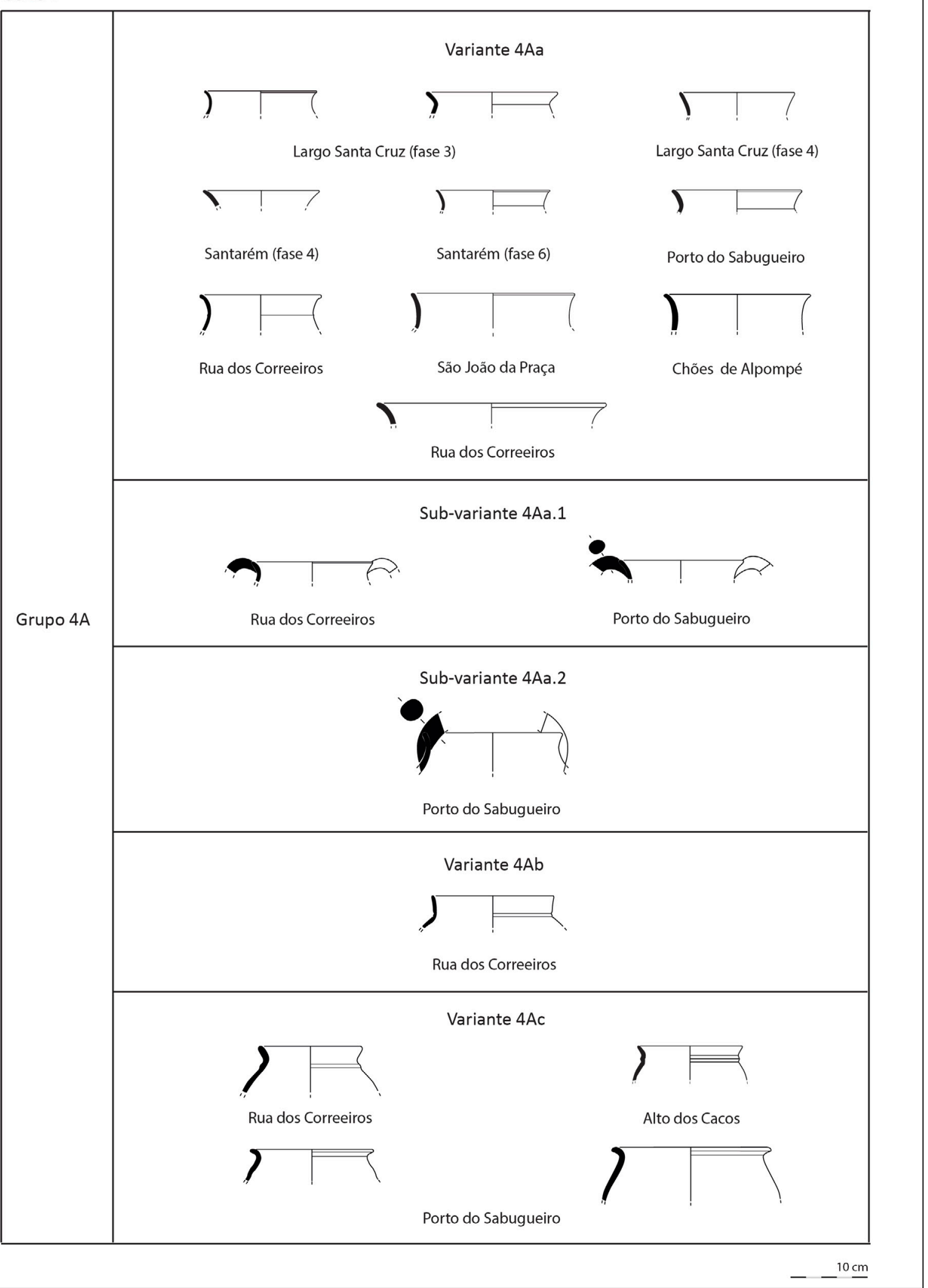

Figura 13. Série 4 do estuário do Tejo (dados recolhidos a partir de Arruda et alii, 2018; Rodrigues et alii, 2019; Pimenta et alii, 2014b; Sousa, 2014; Sousa e Arruda, 2018; Sousa e Guerra, 2018; Sousa et alii, 2016-2017)

Figure 13. Series 4 of the Tagus estuary (data collected from Arruda et al., 2018; Rodrigues et al., 2019; Pimenta et al., 2014b; Sousa, 2014; Sousa and Arruda, 2018; Sousa and Guerra, 2018; Sousa et al., 2016-2017) 
Dimensões: o diâmetro do bordo oscila entre os I3O e os $220 \mathrm{~mm}$.

\section{Variante $4 \mathrm{Cb}$}

Características: distingue-se da anterior pela presença de um lábio pendente.

Cronologia: não sendo ainda possível determinar a sua cronologia inicial, os dados de São João da Praça permitem estabelecer que a forma foi utilizada até ao século in a. C. (Pimenta et alii, 20I4b).

Dimensões: o diâmetro do bordo oscila entre os 2IO e os $216 \mathrm{~mm}$.

\section{Variante 4Cc}

Características: semelhante ao anterior, mas com o colo mais desenvolvido. De todas as variantes do grupo $4 \mathrm{C}$, é a que mais se aproxima da morfologia dos pithoi.

Cronologia: contextualmente encontrado em níveis do século vi a. C., mas é possível que tenha origem num momento mais recuado.

Dimensões: diâmetro do bordo de $160 \mathrm{~mm}$.

Grupo 4D: potes de perfil tronco-cónico

Equivalências tipológicas: não foi possível estabelecer paralelismos com outras morfologias.

\section{Variante 4Da}

Características: os recipientes integrados nesta variante distinguem-se pela quase completa ausência de colo, o que confere a esta peça um perfil mais tronco-cónico. O bordo é evertido, formando um lábio pendente na zona externa.

Identificou-se uma sub-variante (4Da.1) pela presença de uma asa interna, de secção circular, que passa por cima da abertura do vaso.

Cronologia: século v a III a. C.

Dimensões: diâmetro do bordo de I2O mm.

Grupo 4E: potes de bordo vertical

Equivalências tipológicas: não foi possível estabelecer paralelismos com outras morfologias.

\section{Variante $4 \mathrm{Ea}$}

Características: os recipientes caracterizam-se pela presença de um bordo vertical, de secção sub-circular, e ligeiramente espessado no interior. A existência de uma pequena reentrância na zona interna poderia servir de suporte para um qualquer tipo de tampa.

Cronologia: século v a III a. C.

Dimensões: diâmetro do bordo de $126 \mathrm{~mm}$.

\subsubsection{Série 5 (figura 16)}

Designação comum: jarros

Descrição: recipientes fechados, com colo desenvolvido

Funcionalidade: serviço de mesa (serviço de líquidos)

Grupo 5A: jarros de corpo globular e colo tronco-cónico

Equivalências tipológicas: não foi possível estabelecer paralelismos com outras morfologias.

Variante 5Aa

Características: os recipientes desta variante caracterizam-se por apresentarem um corpo tendencialmente globular, a partir do qual arranca um colo desenvolvido. $\mathrm{O}$ bordo é sempre de tendência evertida e de secção sub-circular, podendo por vezes ser aplanado. Nos exemplares que conservam ainda a asa original, de secção circular ou, em certas ocasiões, mais ovalada, esta arranca do bordo, terminando na zona superior do corpo. O colo, de perfil tronco-cónico, apresenta, com frequência, uma ou mais saliências. As bases são aplanadas, podendo exibir um pé destacado. Cronologia: século v a III/II (?) a. C.

Dimensões: o diâmetro do bordo oscila entre os 70 e os $116 \mathrm{~mm}$.

Grupo 5B: jarros de colo estreito e desenvolvido Equivalências tipológicas: não foi possível estabelecer paralelismos com outras morfologias.

\section{Variante 5Ba}

Características: jarros de colo mais desenvolvido e mais estreito, terminando num bordo evertido, simples e contínuo, de secção sub-circular. Num caso, identificado no Cabeço Guião (Arruda et alii, 20I7: fig. 23, n. ${ }^{\circ} 828 \mathrm{I}$ ), que pensamos poder integrar-se nesta variante, a zona do colo apresenta várias saliências. Cronologia: século v a III/II (?) a. C. 
Série 4

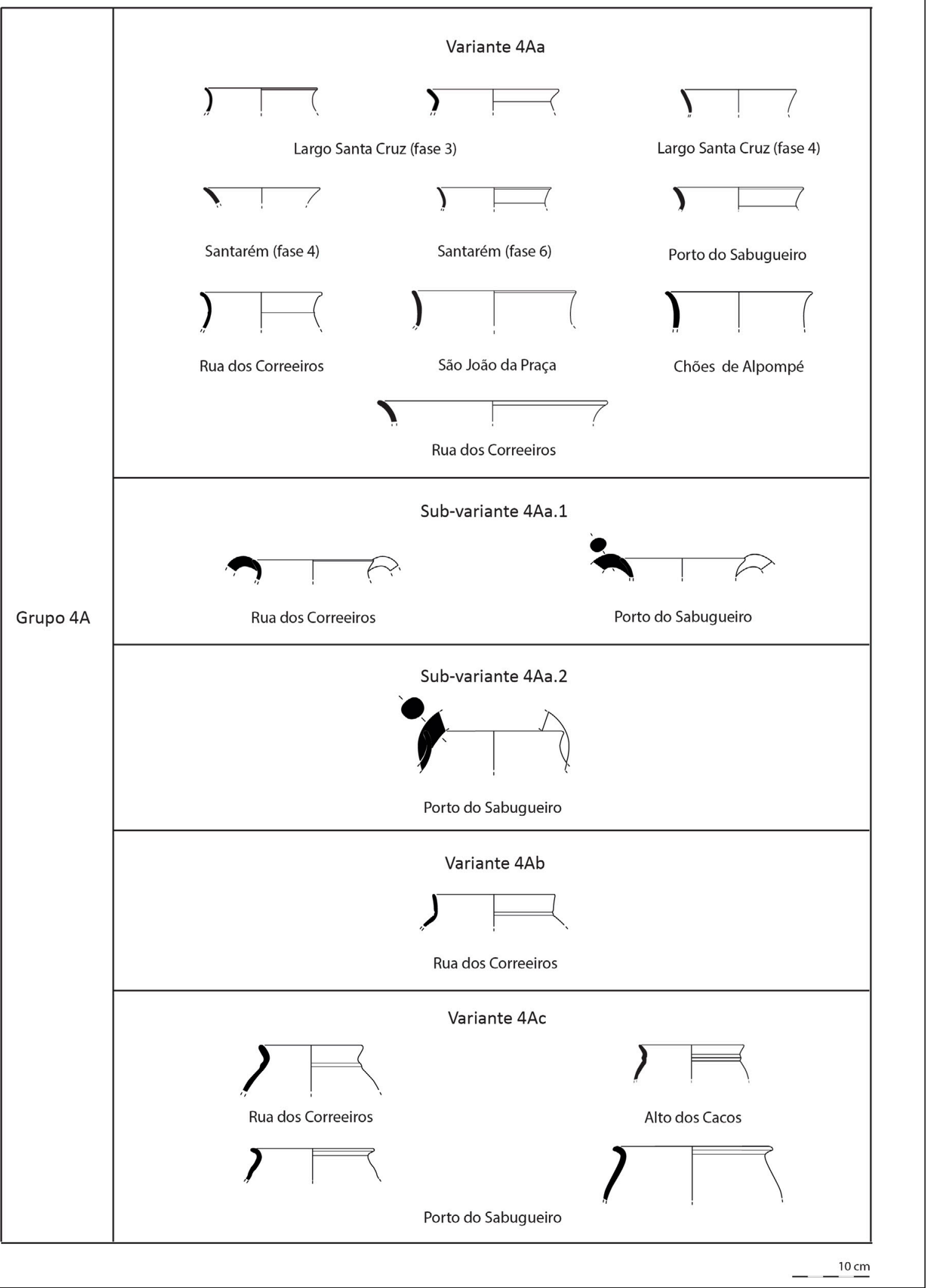

Figura 14. Série 4 do estuário do Tejo (dados recolhidos a partir de Arruda, 1999-2000; Arruda et alii, 2018; Pimenta et alii, 2014b; Rodrigues et alii, 2019; Sousa, 2014; Sousa e Arruda, 2018)

Figure 14. Series 4 of the Tagus estuary (data collected from Arruda, 1999-2000; Arruda et al., 2018; Pimenta et al., 2014b; Rodrigues et al., 2019; Sousa, 2014; Sousa and Arruda, 2018) 
Série 4

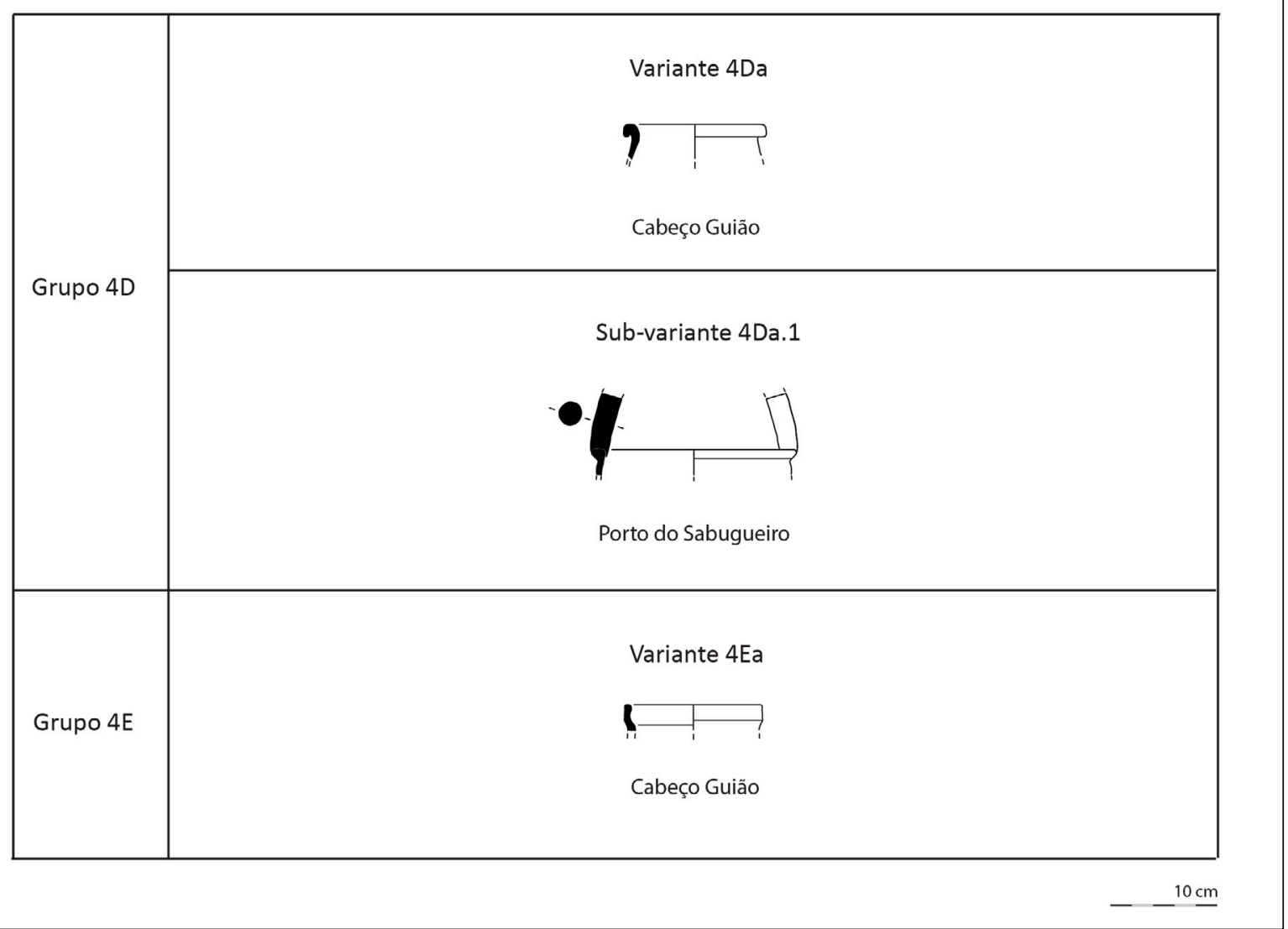

Figura 15. Série 4 do estuário do Tejo (dados recolhidos a partir de Arruda et alii, 2017; Rodrigues et alii, 2019)

Figure 15. Series 4 of the Tagus estuary (data collected from Arruda et al., 2017; Rodrigues et al., 2019)

Dimensões: o diâmetro do bordo oscila entre os II8 e os $\mathrm{I} 44 \mathrm{~mm}$.

\section{Variante $5 \mathrm{Bb}$}

Características: muito semelhante à anterior, distinguindo apenas pela presença de um pequeno lábio pendente.

Cronologia: apenas um exemplar desta forma foi recolhido num nível conservado, com uma datação da segunda metade do século vi a. C. É, contudo, provável que a sua utilização tenha uma cronologia seja mais ampla.

Dimensões: o diâmetro do bordo oscila entre os IOO e os I2O $\mathrm{mm}$.

\subsubsection{Série 6 (figura 17)}

Designação comum: suportes

Descrição: aros baixos
Funcionalidade: primariamente para suporte de outros recipientes. Contudo, convém referir que, recentemente, foi avançada a possibilidade de estes objectos poderem ter sido utilizados como instrumentos musicais (Lorrio, 2008: 714; Vallejo Sánchez, 2015: 351).

Grupo 6A: aros de formato e secção circular Equivalências tipológicas: equivale ao tipo D.II de Vallejo Sánchez (2015), ao tipo 2 de Caro (1989) e ao tipo F1A e F1B de Lorrio (2008).

Variante 6Aa

Características: aros de secção simples.

Cronologia: os exemplares identificados até à data foram recolhidos em contextos do século vi a. C., mas é possível que a sua utilização seja mais prolongada.

Dimensões: diâmetro de $130 \mathrm{~mm}$. 


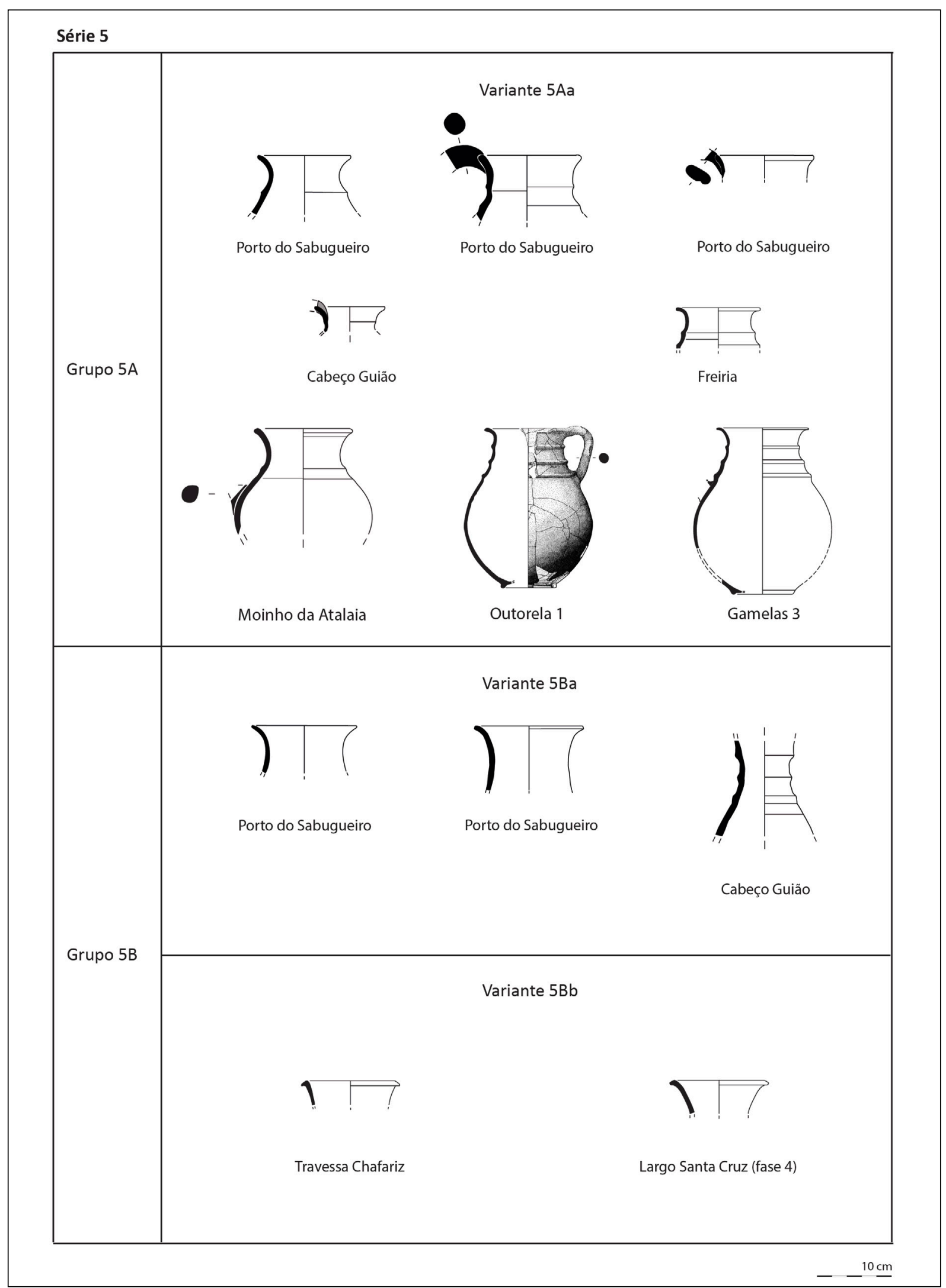

Figura 16. Série 5 do estuário do Tejo (dados recolhidos a partir de Arruda et alii, 2017; Cardoso e Encarnação, 2013; Cardoso e Silva, 2013; Cardoso et alii, 2014; Filipe et alii, 2014; Rodrigues et alii, 2019; Sousa, 2014; Sousa e Guerra, 2018)

Figure 16. Series 5 of the Tagus estuary (data collected from Arruda et al., 2017; Cardoso and Encarnação, 2013; Cardoso and Silva, 2013; Cardoso et al., 2014; Filipe et al., 2014; Rodrigues et al., 2019; Sousa, 2014; Sousa and Guerra, 2018) 
Série 6 e vários

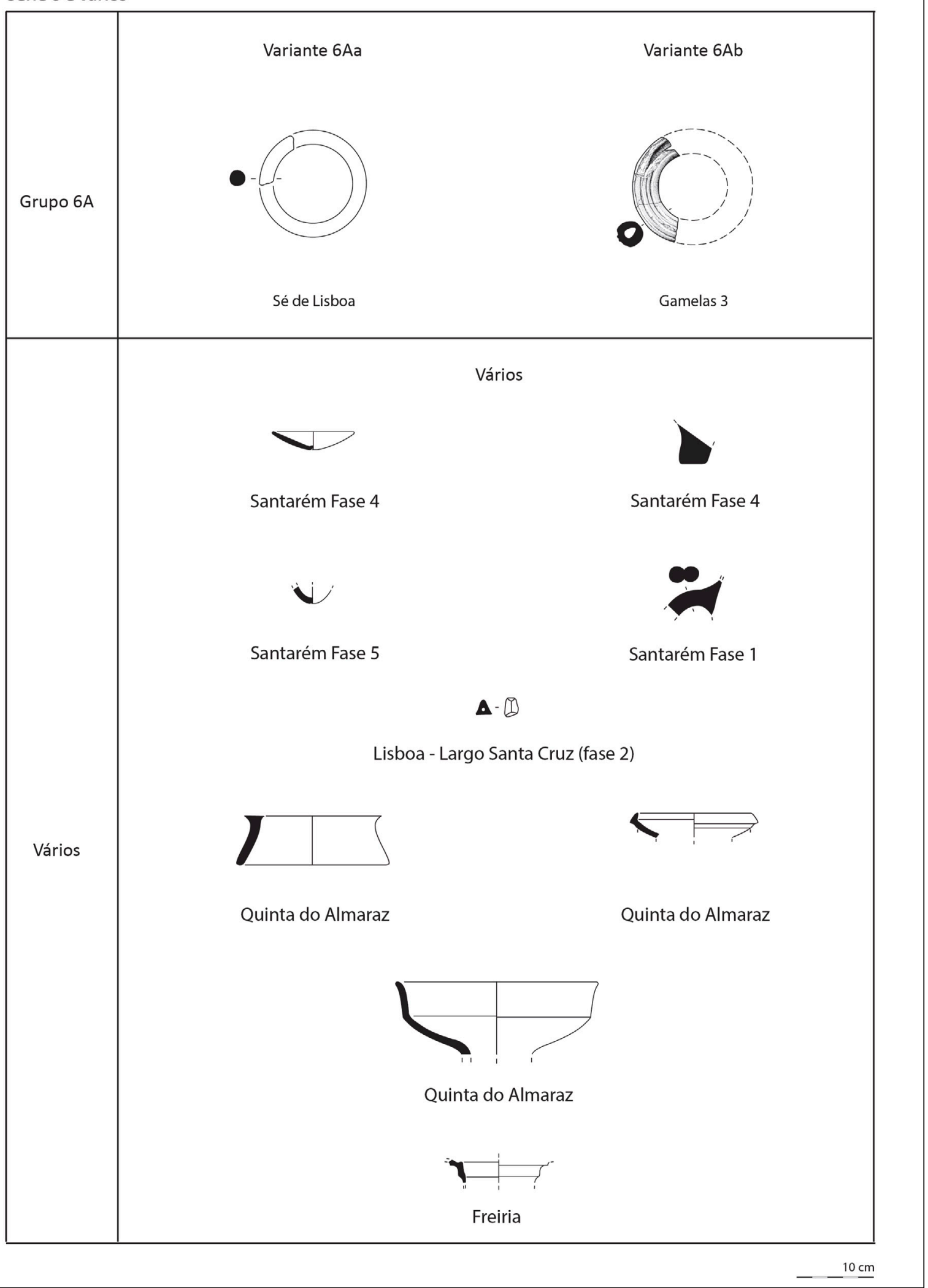

Figura 17. Série 6 do estuário do Tejo e vários (dados recolhidos a partir de Arruda et alii, 2000; Barros e Batalha, 2018; Barros e Henriques, 2002; Cardoso e Encarnação, 2013; Cardoso e Silva, 2013; Sousa e Arruda, 2018; Sousa e Guerra, 2018)

Figure 17. Series 6 of the Tagus estuary and several (data collected from Arruda et al., 2000; Barros and Batalha, 2018; Barros and Henriques, 2002; Cardoso and Encarnação, 2013; Cardoso and Silva, 2013; Sousa and Arruda, 2018; Sousa and Guerra, 2018) 


\section{Variante 6Ab}

Características: aros de secção canelada.

Cronologia: século v e iv a. C.

Dimensões: diâmetro de r6o $\mathrm{mm}$.

\subsubsection{Vários}

Nesta última secção integram-se peças de cerâmica cinzenta de carácter mais singular, mas cuja raridade não justifica, até à data, a sua inclusão em séries autónomas.

Uma significativa parte destas peças provém das escavações realizadas na Alcáçova de Santarém, que proporcionaram um dos conjuntos mais numerosos de cerâmica cinzenta do estuário do Tejo (Arruda, 1999-2000; Sousa e Arruda, 2018). É o caso de uma pequena taça recolhida em níveis datados entre o início e a primeira metade do século vi a. C. (Sousa e Arruda, 20I8: 7I). O exemplar scallabitano, que tem apenas roo $\mathrm{mm}$ de diâmetro, é semelhante a formas enquadradas por Vallejo Sánchez no tipo A.I.1.c (20I5: I43), ainda que estes sejam de cronologias mais tardias. Um outro fragmento singular corresponde a um pequeno pé que poderá ter feito parte de uma trípode, enquadrando-se na mesma cronologia que o caso anterior. Um fragmento de fundo de perfil convexo, recuperado num nível datado de meados / segunda metade do século vi a. C. (Sousa e Arruda, 20I8: 74), poderá, por sua vez, corresponder a uma reprodução de uma oil bottle em cerâmica cinzenta (tipo C.II.8 de Vallejo Sánchez, 20I5; tipo 13 de Caro, I989). Por último, cabe ainda referir um fragmento de asa de secção bífida, recolhido num nível datado de final do século viı / início do século vir a. C. (Sousa e Arruda, 2018: 64), que provavelmente terá sido parte de uma imitação de uma urna tipo Cruz del Negro, ou, ainda mais provavelmente, um pithos (grupo 4C do estuário do Tejo). Já junto à zona terminal do estuário, na colina do Castelo de São Jorge, em Lisboa, cabe destacar um outro fragmento singular de cerâmica cinzenta. Trata-se de um apendículo triangular perfurado, recolhido em níveis datados de momentos tardios do século vir a. C. (Sousa e Guerra, 20I8: 67), que poderá ter feito parte de um alabastrón, semelhante ao tipo E1 de Lorrio (2008).
Na margem oposta, na Quinta do Almaraz, foram também recuperadas algumas peças singulares de cerâmica cinzenta. É o caso de um suporte de perfil troncocónico (Barros e Batalha, 20I8), com I78 mm de diâmetro máximo, e que se enquadra facilmente no tipo D.I.2 de Vallejo Sánchez (2015). Ainda que esta forma seja, até ao momento, singular no quadro do repertório da cerâmica cinzenta da Baixa Estremadura, cabe recordar que peças com morfologias semelhantes se conhecem em cerâmica comum, com cronologias centradas nos meados do I ${ }^{\mathrm{o}}$ milénio a. C. (Sousa, 20I4). Emblemático é também o fragmento de da parte superior de uma pequena trípode (Barros e Batalha, 20I8), com $\mathrm{I} 20 \mathrm{~mm}$ de diâmetro. Uma outra peça proveniente da Quinta do Almaraz oferece maiores dificuldades no que diz respeito à sua classificação. Trata-se de um recipiente carenado, com $250 \mathrm{~mm}$ de diâmetro (Barros e Henriques, 2002), que poderia até enquadrar-se no grupo 1B definido para o estuário do Tejo. Contudo, o arranque para a zona terminal desta peça poderia indicar que se tratasse de algum tipo de funil, razão pela qual optámos por colocá-la nesta secção.

Por último, cabe ainda referir um fragmento recuperado em Freiria (Cardoso e Encarnação, 2013), que parece corresponder à parte inferior de uma pátera. Seria possível associar este fragmento à variante $2 \mathrm{Ac}$, tendo em conta que recipientes com idênticas morfologias, ainda que com perfis mais bem conservados, foram já recuperados na zona do Tejo, em produções de cerâmica de engobe vermelho e cerâmica comum (Barros et alii, I993; Sousa, 2014; Arruda et alii, 20I7).

\section{Evolução e perfis de consumo da cerâmica cinzenta no estuário do Tejo}

Como já foi anteriormente referido, a cerâmica cinzenta é consideravelmente abundante no centro da costa ocidental atlântica da Península Ibérica. $\mathrm{Na}$ zona da Baixa Estremadura, as escavações que foram realizadas, sobretudo, durante as últimas duas décadas, têm permitido adquirir dados sempre mais precisos sobre os ritmos de consumo desta categoria ao longo do $\mathrm{I}^{\mathrm{o}}$ milénio a. $\mathrm{C}$.

Começando pela zona terminal do estuário do Tejo, e mais concretamente no núcleo da colina do 
Castelo de São Jorge, em Lisboa, as escavações realizadas no Largo de Santa Cruz permitiram recuperar uma sequência estratigráfica que abrange o período compreendido entre o século viI e o século v a. C. (Sousa e Guerra, 2018). O espólio recolhido nestas intervenções é consideravelmente abundante e a cerâmica cinzenta está presente ao longo de toda a diacronia. Nos níveis mais antigos deste espaço, datados do século viı a. C., a sua expressividade oscila entre os $13,60 \%$ (6 NMI) e os I $2,00 \%$ (5 NMI), aumentando de forma significativa durante o século vi a. C., período durante o qual constitui entre 22,80 \% (2I NMI) e 36,80 \% (II4 NMI) dos conjuntos artefactuais. Durante o século v a. C., a cerâmica cinzenta mantém esta representatividade, com 35, I4 \% (I3 NMI) da totalidade do repertório (Sousa e Guerra, 20I8). No que diz respeito às formas, no período mais antigo dominam as tigelas (grupo 1A) e pequenas taças (grupo 3E), morfologias que se mantém durante o século vi a. C., mas às quais agora se somam os pratos (grupo $2 \mathrm{C}$ ), os pequenos potes (grupo 3D) e vasos de maiores dimensões (grupo 4Aa). É também nesta fase do século vi a. C. que se verifica a introdução das tigelas de bordo reentrante (variante $1 \mathrm{Ca}$ ), das taças de perfil acampanado (variante $3 \mathrm{Fd}$ ) e dos primeiros jarros (variante $5 \mathrm{Bb}$ ), não sendo também impossível que, nos momentos finais da centúria, se observe já a emergência dos pequenos potes da variante $3 \mathrm{Aa}$, cuja produção se irá, contudo, acentuar de forma mais significativa na fase posterior. Para a segunda metade do século vi a. C., contamos ainda, em Lisboa, com os dados recolhidos nas escavações realizadas na Sé (Arruda et alii, 2000), que nos permitem acrescentar ao repertório desta fase os aros cilíndricos da variante $6 \mathrm{Aa}$.

$\mathrm{Na}$ zona terminal do estuário, cabe dar também destaque ao extenso conjunto recolhido na Quinta do Almaraz (Henriques, 2006; Barros e Henriques, 2002; Barros e Soares, 2004; Barros e Batalha, 2018), e que apresenta uma situação muito semelhante à detectada na outra margem, destacando-se, contudo, pelo carácter singular de alguns dos artefactos. Infelizmente, os dados disponíveis sobre este importante sítio não permitem ainda precisar com detalhe os conjuntos artefactuais associados às diferentes fases de ocupação dentro da Idade do Ferro, ainda que esta se centre, sobretudo, entre o período orientalizante e os meados do $\mathrm{I}^{\mathrm{o}}$ milénio a. C. (Barros et alii, 1993; Barros e Soares, 2004; Arruda, 2005; Olaio, 2018; Sousa, 2018).

Para esta fase da I I Idade do Ferro, é importante contrastar os dados recolhidos em Lisboa e Almaraz, e cuja ocupação tem sido recentemente interpretada no quadro de uma fundação de natureza colonial (Sousa, 2015, 2016, 2018), com os provenientes de núcleos de povoamento de tradição claramente indígena, que se localizam na zona mais interior do estuário, e entre os quais a Alcáçova de Santarém assume uma posição de destaque pela expressividade e qualidade dos dados arqueológicos adquiridos. A grande expressividade da cerâmica cinzenta no sítio (Arruda, I999-2000) foi corroborada, uma vez mais, em escavações realizadas no início do século xxi (Sousa e Arruda, 20r8), que permitiram documentar uma sequência estratigráfica bem conservada, formada entre o final do século viı / início do século vir a. C. e o final do século vi a. C. Nos momentos mais antigos, a cerâmica cinzenta forma já uma parte significativa do conjunto exumado, oscilando entre os $18,60 \%$ (32 NMI) e os 13,29 \% (I9 NMI). A partir da segunda metade do século vir a. C., a sua presença torna-se progressivamente mais expressiva, situação que se relaciona também com a redução do consumo de produções manuais no local (Sousa e Arruda, 2018). Com efeito, entre a segunda metade do século vir a. C.e a transição para a centúria seguinte, as produções cinzentas passam a constituir entre 31,13 \% (47 NMI) e 47,21 \% (5I NMI) dos conjuntos cerâmicos recuperados, aumentando, durante o século vi a. C., para 44,55 \% (53 NMI) e 63,54 \% (I29 NMI). Trata-se de valores bem mais expressivos do que os que foram documentados em Lisboa, em níveis contemporâneos, demonstrando o sucesso que esta categoria obteve entre as comunidades indígenas do estuário, situação que, aliás, ocorre também em contextos similares de outras regiões peninsulares (ver, entre outros, Vallejo Sánchez, 20I5). Contudo, é interessante notar que os perfis de consumo da Alcáçova de Santarém demonstram certas particularidades, sobretudo no que diz respeito às morfologias mais adoptadas e/ou 
reproduzidas. Enquanto que, em Lisboa, as formas preferenciais de cerâmica cinzenta integram as tigelas (grupo 1A) e taças / potes de dimensão reduzida (grupos 3D e 3E), na Alcáçova de Santarém as tipologias mais próximas às tradições de cerâmica manual da fase final da Idade do Bronze são francamente expressivas. Com efeito, os recipientes que integrámos nas variantes $3 \mathrm{Fa}, 3 \mathrm{Fb}$ e $3 \mathrm{Fc}, 3 \mathrm{Fe}, 3 \mathrm{Ff}$, $3 \mathrm{Fg}$ e $3 \mathrm{Fh}$, e que recordam claramente as pequenas taças de perfil simples e carenado utilizadas durante o Bronze Final (Arruda e Sousa, 2015), foram recolhidos sobretudo nesta região mais interior do estuário, sendo a esmagadora maioria proveniente da própria Alcáçova de Santarém. Esta tendência é, por um lado, um forte indicador da existência de zonas de produção próprias desta área e, simultaneamente, reflete também as tendências da adopção, por parte das comunidades indígenas do estuário, das tecnologias de produção fenício-ocidentais dentro de critérios e tradições nativas. Contudo, e paradoxalmente, é também no quadro destes sítios de carácter indígena que iremos encontrar com mais frequência emulações de morfologias atípicas no repertório da cerâmica cinzenta regional, como é o caso dos pithoi (variante $4 \mathrm{Cc}$ ), e de possíveis imitações de trípodes e oil bottles (figuras I8, 19, 20 e 2I).

A cerâmica cinzenta da segunda metade do $\mathrm{I}^{\mathrm{o}}$ milénio a. C. caracteriza-se, no estuário do Tejo, pela consolidação de um repertório regional próprio, que se inicia seguramente ainda na fase anterior, mas que adquire as suas características mais singulares entre o século v e o século III a. C. $\mathrm{Na}$ sequência de um período que parece ter sido marcado por um certo isolamento no que concerne aos contactos supra-regionais (Arruda, 1999-2000, 2005; Sousa, 20I4, 20I7), as diversas categorias cerâmicas da Baixa Estremadura passam a assumir aspectos particulares (Sousa, 20I4), situação que irá também afectar as produções cinzentas. É o caso das tigelas com perfis canelados (grupo 1D), que surgem associadas a sítios com ocupações mais tardias, como é o caso de Freiria (Cardoso e Encarnação, 2013) e do Cabeço Guião (Arruda et alii, 20I7), e das tigelas / pratos de perfis carenados (grupo 2A), que podem ter uma origem anterior, mas que atingem $\mathrm{O}$ seu auge justamente durante os séculos v/Iv a. C.
(Sousa, 20I4). Outras formas características deste período e desta região são os pratos de perfil moldurado (variante $2 \mathrm{Ba}$ ) e os pequenos potes (grupo $3 \mathrm{~A}$, 3B, 3C). De cronologia ainda incerta (Sousa, 2016; Sousa e Pimenta, 20I7), mas cuja origem poderá remontar aos momentos mais tardios da Idade do Ferro, são os vasos com influências helenísticas (grupo $3 G$ ). A esta e às outras formas da série 3 , cuja morfologia remete primariamente para o consumo individual de líquidos, devem associar-se os jarros (série 5) que são particularmente recorrentes em sítios ocupados durante a segunda metade do $\mathrm{I}^{\circ} \mathrm{mi}-$ lénio a. C., como é o caso dos Moinhos da Atalaia (Sousa, 2014), Outorela (Cardoso, 2004; Cardoso et alii, 20I4), Gamelas 3 (Cardoso e Silva, 2013) e Cabeço Guião (Arruda et alii, 20I7). É muito provável que os jarros de cerâmica cinzenta de boca trilobada e com decorações brunidas, que surgem com alguma frequência associados a níveis romano-republicanos na área do Tejo, sejam uma evolução dos protótipos da Idade do Ferro, podendo ter surgido ainda durante os momentos finais da Idade do Ferro (Pimenta et alii, 2005; Pimenta et alii, 2010, 2014a e 20I4b; Mota et alii, 20I4). Um último aspecto que deve ser referido relaciona-se com alguns vasos que apresentam asas internas, e que integram as sub-variantes 4Aa.1 e4Da.1. Infelizmente, estes exemplares, recolhidos no Porto do Sabugueiro (Rodrigues et alii, 2019), não possuem um contexto que permita definir a sua cronologia. Contudo, cabe referir que a presença destas asas internas está documentada em produções de cerâmica comum a partir do século v a. C. (Sousa, 2014), podendo assumir-se uma cronologia semelhante para as referidas sub-variantes de cerâmica cinzenta.

Resta referir que nestes momentos centrados entre o século v e III a. C., a cerâmica cinzenta continua a ser expressiva nos reportórios artefactuais do estuário do Tejo. Entre os vários núcleos de pequena dimensão localizados a ocidente de Lisboa, e cuja ocupação se centra justamente nesta fase, destaca-se a expressividade das produções cinzentas em sítios como Outorela r e 2, com 39,72 \% e 29,63\%, respectivamente (Cardoso et alii, 20I4), ou o Moinho da Atalaia, com 26,19 \% (I27 NMI) (Sousa, 20I4).Já em sítios com que podem ter desempenhado funções 


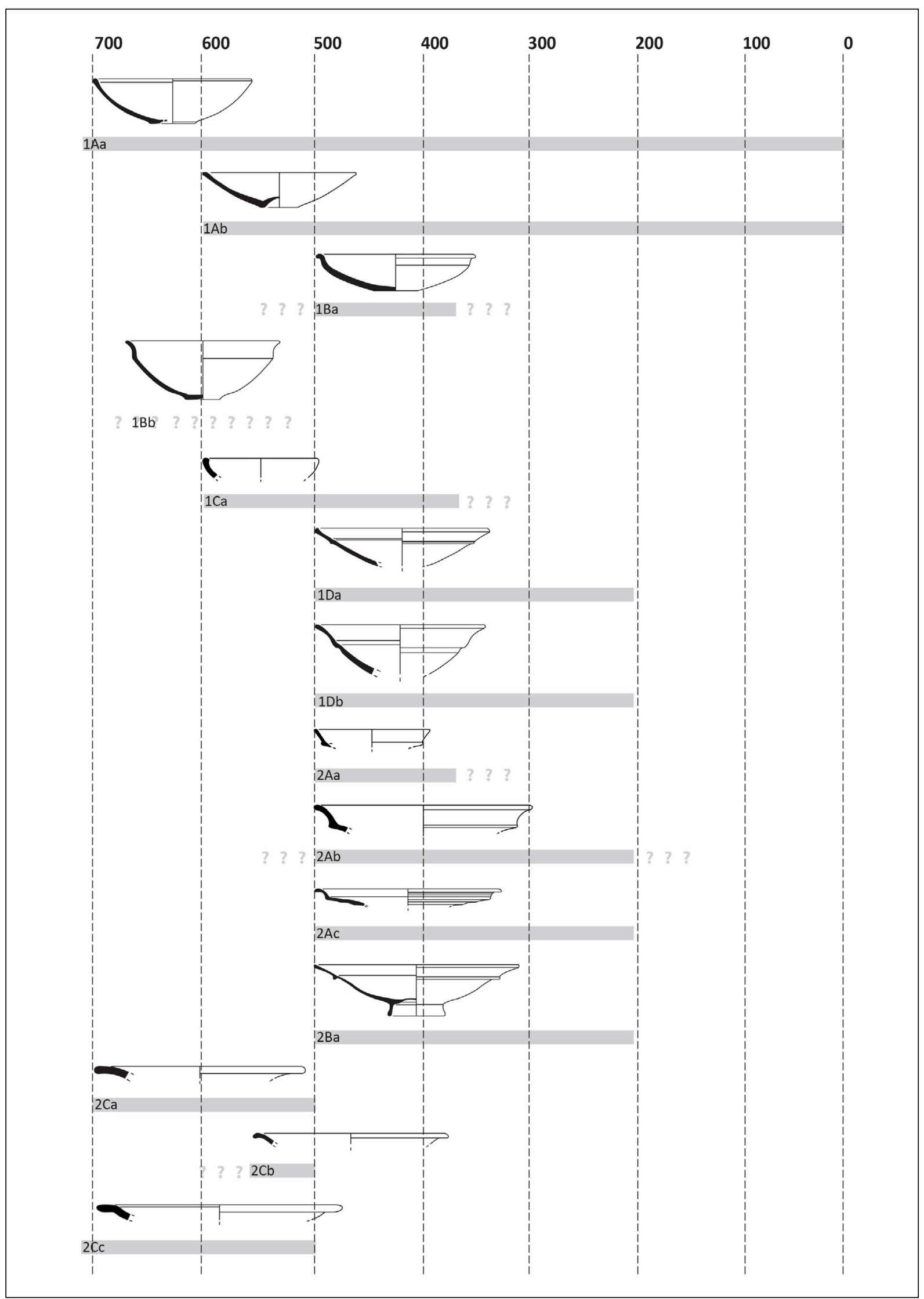

Figura 18. Quadro evolutivo das séries 1 e 2 do estuário do Tejo

Figure 18. Evolution of series 1 and 2 of the Tagus estuary 


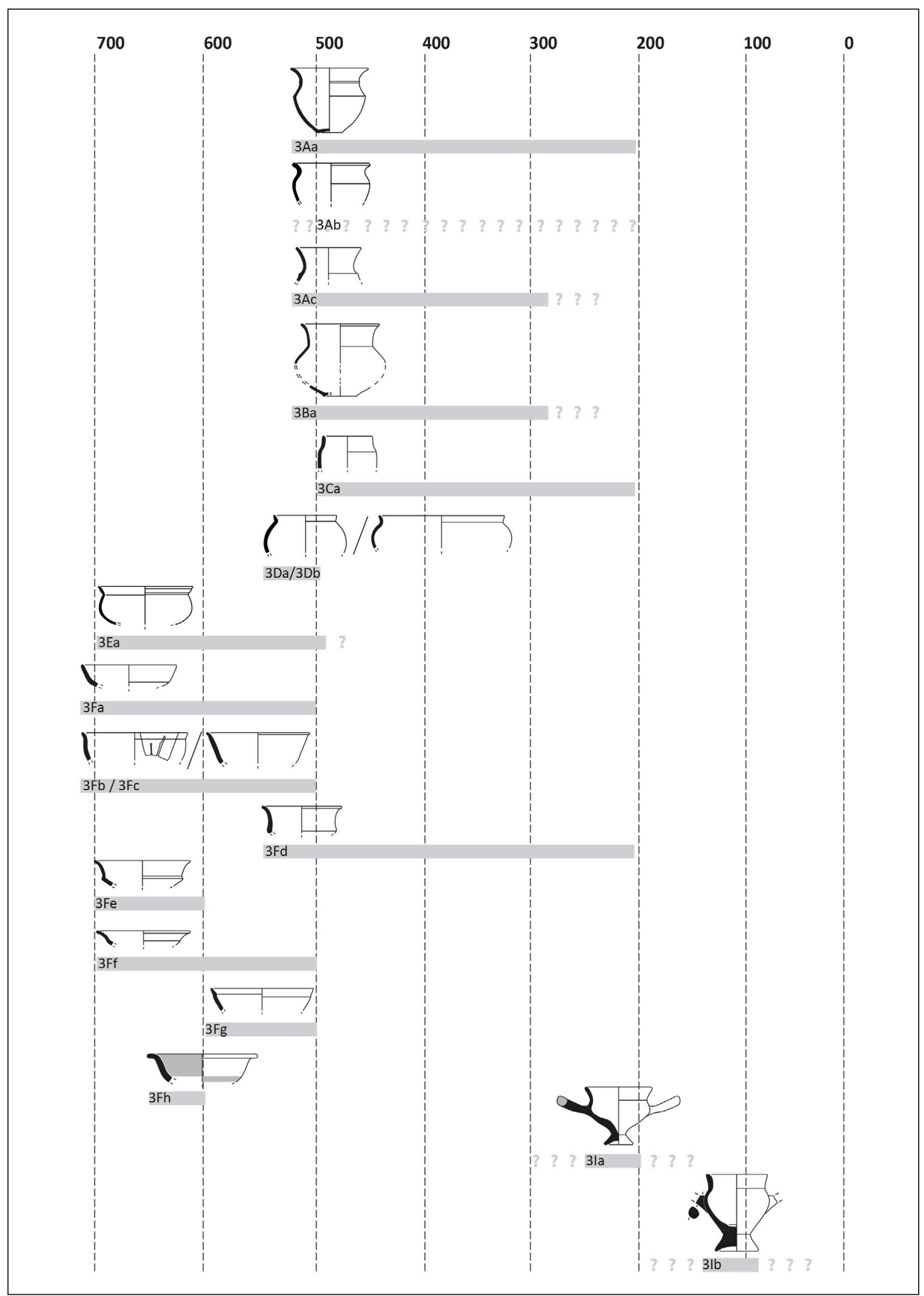

Figura 19. Quadro evolutivo da série 3 do estuário do Tejo

Figure 19. Evolution of series 3 of the Tagus estuary 


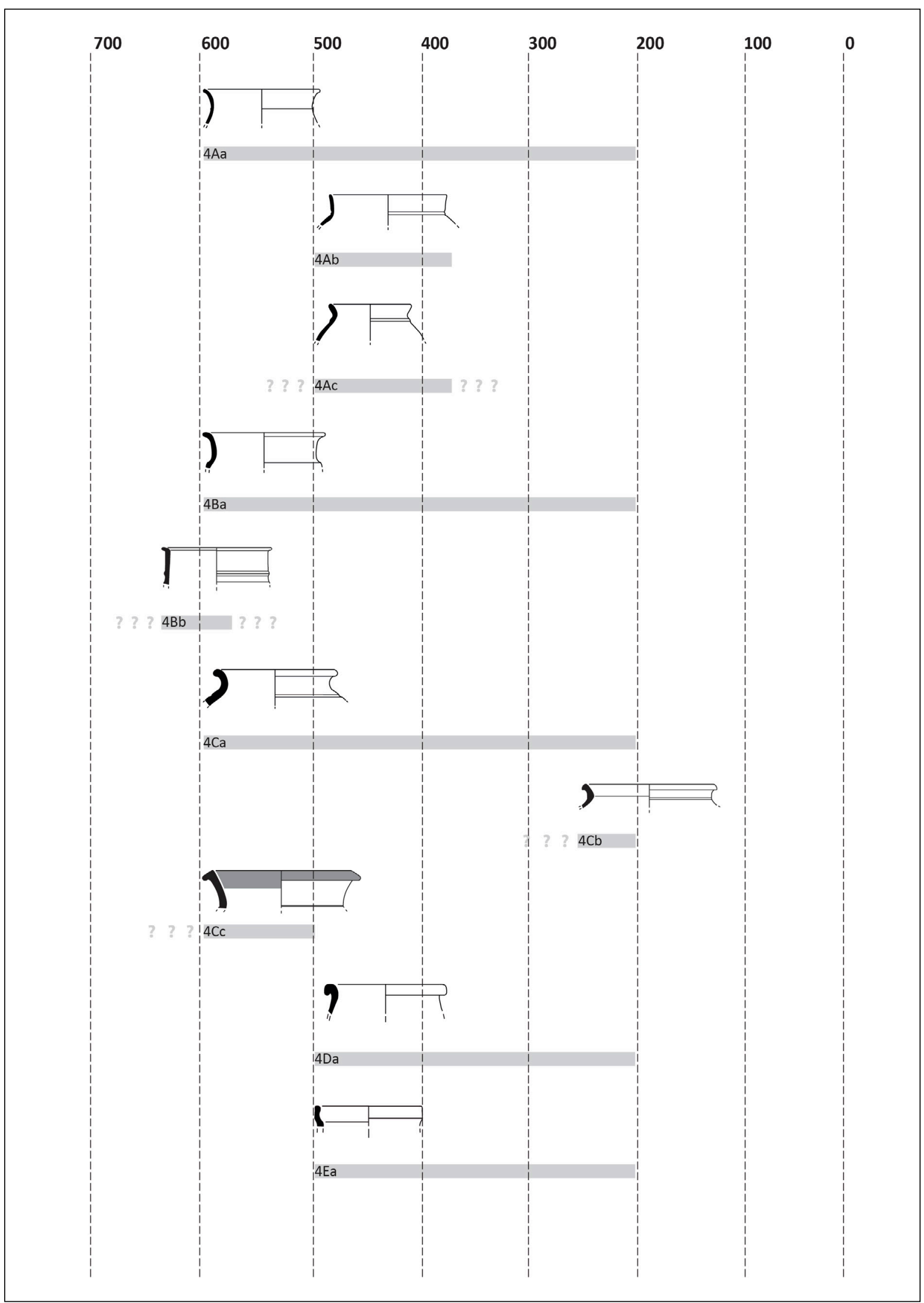

Figura 20. Quadro evolutivo da série 4 do estuário do Tejo

Figure 20. Evolution of series 4 of the Tagus estuary 


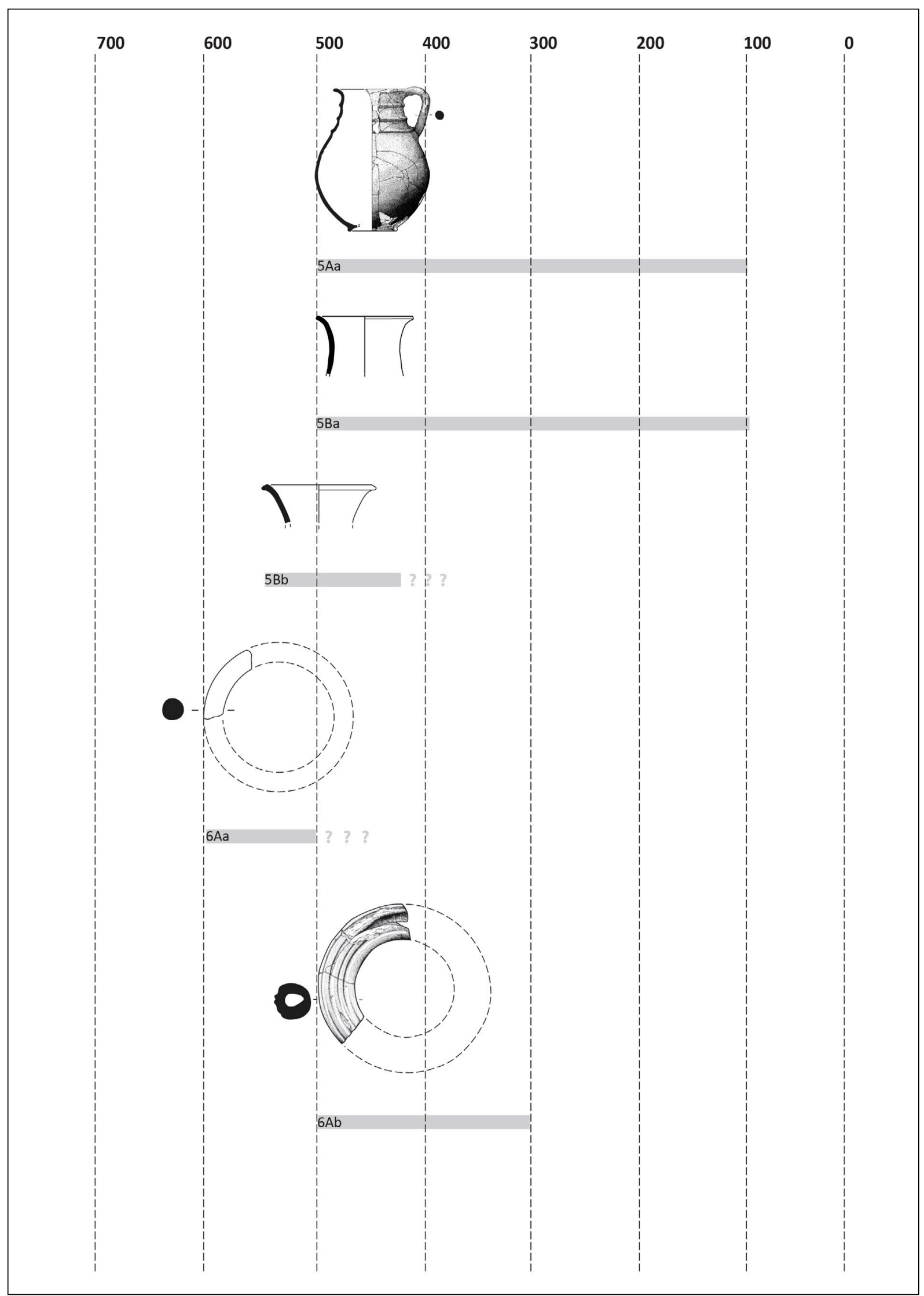

Figura 21. Quadro evolutivo das séries 5 e 6 do estuário do Tejo

Figure 21. Evolution of series 5 and 6 of the Tagus estuary 
mais eminentes na organização desta malha de povoamento, como Baútas ou Santa Eufémia, e cujas ocupações podem ter-se iniciado um pouco antes, mas que seguramente abarcam também a segunda metade do $\mathrm{I}^{\mathrm{o}}$ milénio a. C., a cerâmica cinzenta é um pouco menos expressiva, correspondendo, respectivamente, a 15,50 \% (3I NMI) e I2, I5 \% (I3 NMI) do espólio recuperado (Sousa, 20I4).

Nesta fase tardia, a cerâmica cinzenta é também significativa na zona mais interior do estuário, ainda que na grande maioria dos sítios onde foi a estratigrafia arqueológica não esteja bem conservada (Arruda et alii, 20I4; Sousa et alii, 2016-2017; Pimenta et alii, 2018, 2019; Rodrigues et alii, 2019). A excepção a esta situação verifica-se no Cabeço Guião, um local ocupado entre o final do século v e o século iII a. C., e onde as produções cinzentas constituem 18,37\% (I54 NMI) do repertório exumado em contextos conservados (Arruda et alii, 2017).

Na colina do Castelo de São Jorge, em Lisboa, este momento da Idade do Ferro está bem caracterizado na Rua dos Correeiros, cuja ocupação se centra entre os meados do primeiro milénio e o início do século Iv a. C. Contudo, neste caso, a cerâmica cinzenta é menos expressiva, correspondendo, com $245 \mathrm{NMI}$, a apenas $8,36 \%$ do repertório exumado (Sousa, 20I4), situação que poderá estar relacionada com aspectos funcionais deste espaço, aparentemente mais ligado a actividades de cariz artesanal ou mesmo com funções portuárias (Sousa, 20I4; Cardoso et alii, 20I7).

Os dados disponíveis para os momentos finais da Idade do Ferro e a fase de transição para o período romano-republicano são, infelizmente, ainda escassos, dificultando a compreensão da evolução deste repertório e a sua transição para uma nova esfera política, económica e comercial. Em Lisboa, apenas os dados recolhidos na Rua de São João da Praça são representativos deste momento (Pimenta et alii, 2005, 2014b). Contudo, parece evidente que as produções cinzentas vão, efectivamente, transitar para o período romano, sendo utilizadas, pelo menos, até à viragem da era. Com efeito, a existência destas produções em contextos de época romano-republicana é uma realidade, sendo perceptíveis alterações morfológicas significativas, que são influenciadas e, em alguns casos, emulam as produções itálicas de cerâmicas de mesa de verniz negro e de terra sigillata (Bugalhão et alii, 20I3). Será necessário, no futuro, e com base em dados contextuais mais precisos, analisar com mais detalhe a evolução do repertório da cerâmica cinzenta neste novo contexto histórico.

Num quadro geral, e apesar das semelhanças que se podem traçar entre o repertório de cerâmica cinzenta do estuário do Tejo e outros definidos para várias zonas da Península Ibérica, é necessário individualizar certas tendências mais particulares que se verificam na fachada ocidental atlântica e, mais especificamente, na Baixa Estremadura. Ainda que a grande representatividade das tigelas (grupo I) seja transversal a várias regiões, a zona do Tejo distingue-se pela quase idêntica preferência, ao longo de todo o $\mathrm{I}^{\mathrm{O}}$ milénio, de pequenos recipientes destinados ao consumo de líquidos. Durante a fase mais antiga, estes correspondem sobretudo a taças (grupos $3 \mathrm{E}$ e $3 F$ ) que, nos momentos centrais do $\mathrm{I}^{\mathrm{o}}$ milénio a. $\mathrm{C}$., evoluem para formas mais fechadas (primeiro grupo $3 \mathrm{D}$ e, posteriormente, grupos $3 \mathrm{~A}, 3 \mathrm{~B}$ e $3 \mathrm{C}$ ). A importância destas tradições relacionadas com o consumo de líquidos verifica-se também na presença de jarros (série 5), uma forma que não é frequente em outras regiões peninsulares, mas que é relativamente frequente na Baixa Estremadura, e que irá transitar inclusivamente para as primeiras etapas do período romano (Pimenta et alii, 20I4a; Mota et alii, 20I4). Menos expressivas são as séries 2 (tigelas / pratos) e 4 (vasos de armazenamento), cuja funcionalidade seria desempenhada sobretudo pelas produções de cerâmica de engobe vermelho e de cerâmica comum.

Naturalmente que estas tendências, e o próprio ensaio tipológico que foi aqui apresentado, não é ainda definitivo, sobretudo quando se refere a produções pouco estandardizadas e cujos repertórios variam em directa correlação com a multiplicidade de centros produtores, ainda que sempre dentro de uma mesma escala regional. Contudo, a proliferação dos dados sobre a utilização da cerâmica cinzenta ao longo dos últimos anos, e sobretudo a possibilidade da sua conjugação a parâmetros cronológicos cada vez mais bem definidos, justificam este esforço de criar uma tabela de referência capaz de simplificar e sistematizar novos estudos sobre aspectos concretos da cultura material na Baixa Estremadura. 


\section{Conclusão}

A emergência da cerâmica cinzenta no estuário do Tejo é um fenómeno que se encontra indubitavelmente associado com a instalação de grupos fenícios ocidentais na região a partir dos finais do século viı a. C. Estas comunidades trazem consigo não apenas novas tecnologias de produção oleira, mas também um pacote artefactual já plenamente consolidado, e que é o resultado de processos de interacção cultural ocorridos no sul andaluz, e onde estas produções cinzentas refletem a hibridação de tecnologias forâneas e tradições e gostos locais.

Tal como ocorre nas restantes áreas peninsulares, esta categoria cerâmica está vocacionada primariamente para o serviço de mesa, função que comparte com outras produções de matriz cultural fenícia, como é o caso da cerâmica de engobe vermelho e da cerâmica comum (Arruda, 1999-2000; Sousa, 2016), mas também com vasos manuais que mantêm ainda as preferências estéticas e morfológicas do Bronze Final regional. Esta última convivência é particularmente expressiva em sítios de matriz cultural indígena, como é o caso da Alcáçova de Santarém (Arruda, I999-2000; Sousa e Arruda, 2018), estando, porém, também documentada, e ainda que de forma mais discreta, nos repertórios artefactuais de Lisboa/Almaraz, sobretudo nos níveis do século viI e vi a. C. (Arruda, 1999-2000; Sousa e Pinto, 2016; Sousa e Guerra, 2018).

A criação de novos centros oleiros na área do Tejo, com tecnologias e tradições integráveis na esfera fenícia-ocidental, e que têm na cerâmica cinzenta um dos seus principais produtos, gerou, inevitavelmente, uma evolução paralela a outras linhas do sul e interior peninsular. Existem, naturalmente, tendências mais transversais, que se detectam não só na própria cadeia operatória da manufactura destes vasos, mas também em morfologias quase universais, como é o caso das tigelas de perfil semi-hemisférico e carenado, ou dos pratos que se inspiram em protótipos de cerâmica de engobe vermelho, e que se registam em grande parte das regiões do centro e sul da Península Ibérica. Mas paralelamente surgem também formas mais particulares, como é o caso, na área do Baixo Tejo, dos pequenos potes/taças e dos recipientes destinados ao serviço de líquidos, que devem ser entendidos como expressões de ulteriores fenómenos de contactos inter-culturais que ocorrem entre as comunidades fenícias-ocidentais e os grupos indígenas pré-existentes.

Com efeito, é notável o sucesso que as produções cinzentas obtiveram no seio dos núcleos autóctones centro-atlânticos, e que se reflete não apenas na sua adopção como um dos principais componentes do serviço de mesa, mas provavelmente também na emergência de áreas de produção próprias. E ainda que a tecnologia inerente ao fabrico destas cerâmicas cinzentas (torno rápido e estruturas de combustão de câmara dupla) implique processos de aprendizagem ou mesmo uma instalação, nesses núcleos, de agentes forâneos que dominam esse know-how, as morfologias mais apreciadas reentram nos cânones morfo-funcionais de tradição do Bronze Final, como se reflete no repertório artefactual de sítios como a Alcáçova de Santarém (Arruda, I999-2000; Sousa e Arruda, 2018).

Esta putativa multiplicidade de centros produtores, apesar de ainda não estar comprovada arqueologicamente, permitiria compreender algumas diferenças registadas na análise comparativa dos repertórios de cerâmica cinzenta de Lisboa/Almaraz e da Alcáçova de Santarém, sobretudo no que diz respeito às variantes da série 3 . Com efeitos, os vasos que reproduzem morfologias mais típicas do horizonte do Bronze Final adquirem uma presença muito mais expressiva nas zonas mais interiores do estuário (variantes $3 \mathrm{Fa}, 3 \mathrm{Fb}$ e $3 \mathrm{Fc}$ ), enquanto que na foz a preferência recai sobre pequenos vasos de perfil globular ou ovalado (variantes $3 \mathrm{Da}, 3 \mathrm{Db}$ e $3 \mathrm{Ea}$ ). Assim, e ainda que partilhem uma funcionalidade comum, certas preferências e gostos individuais e comunitários terão ditado as normas produtivas dos diferentes centros de fabrico de cerâmicas cinzentas da região tagana.

Estas disparidades atenuam-se a partir de meados do $\mathrm{I}^{\mathrm{o}}$ milénio a. C., momento a partir do qual o repertório morfológico das produções cinzentas se torna bastante homogéneo no Baixo Tejo (Sousa, 20I4). Esta situação pode justificar-se pela hegemonia que o núcleo de Lisboa parece ter adquirido nesta fase, tendo sido provavelmente o grande promotor da 
reestruturação da malha de povoamento e dos circuitos económicos e comerciais de grande parte da região, e também o principal produtor e abastecedor de vasos cerâmicos dos múltiplos núcleos agora ocupados (Sousa, 2014, 2017). Ainda assim, não se pode excluir a possibilidade de outros centros de menor entidade se terem dedicado também à manufactura destas cerâmicas, quer em zonas mais interiores do estuário, quer na área mais ocidental da Península de Lisboa, mas que permanecem ainda por caracterizar devidamente. De qualquer forma, é sobretudo neste momento de meados do $\mathrm{r}^{\mathrm{o}}$ milénio a. C. que surgem as formas mais típicas deste horizonte regional, sendo de assinalar uma maior preferência por perfis

\section{Bibliografia}

Almagro Basch, M. (I949): "Cerámica griega gris de los siglos vi-v a.C. en Ampurias”. Rivista di Studi Liguri, 15: 62-122.

Arruda, A.M. (1999-2000): Los Fenicios en Portugal. Fenicios y mundo indígena en el centro y sur de Portugal (siglos VIII-VI a.C.). Universidad Pompeu Fabra. Barcelona.

Arruda, A.M. (2005): "O I ${ }^{\circ}$ milénio a.n.e. no Centro e no Sul de Portugal: leituras possíveis no início de um novo século". O Arqueólogo Português, IV-3: 9-I56.

Arruda, A.M., Freitas, V.e Vallejo Sánchez,J. (2000): "As cerâmicas cinzentas da Sé de Lisboa". Revista Portuguesa de Arqueologia, 3 (2): 25-59.

Arruda, A.M., Pereira, C., Sousa, E., Pimenta, J., Detry, C. e Gomes, J. (2018): “Chões de Alpompé (Vale de Figueira, Santarém): Lendas e Narrativas". SPAL, 27 (2): 20I-227. <https://doi. org/Io.12795/spal.2018i27.20>.

Arruda, A.M., Sousa, E. (20I9): "The Greek pottery of the Tagus estuary”. Em R. Morais, D. Leão, D. Pérez e D. Ferreira (eds.): Greek Art. Studies in honour of Sir John Boardman on the occasion of his $9 \mathrm{o}^{\text {th }}$ birthday. Archaeopress. Oxford: 187-I95. carenados e moldurados, mas também uma maior diversidade morfológica, dentro da qual se sublinha uma maior difusão de recipientes destinados ao serviço de líquidos (série 5) e de pequenos vasos para beber (tipos 3A,3B e 3C), o que revela algumas alterações nos hábitos de comensalismo. Neste âmbito, permanece ainda por esclarecer a cronologia exacta de certas influências helenísticas que se verificam em algumas morfologias (tipo 3I). Apesar de ser tentador associar este fenómeno à fase de maior incidência de cerâmicas gregas do período clássico na região (Arruda e Sousa, 20I9), será necessário atender a novos dados cronológicos seguros que permitam antecipar com segurança a sua cronologia.

Arruda, A.M., Sousa, E., Barradas, E., Batata, C., Detry, C. e Soares, R. (20I7): “O Cabeço Guião (Cartaxo - Portugal): um sítio da Idade do Ferro do Vale do Tejo". Em S. Celestino Pérez e E. Rodríguez González (eds.): Territorios comparados: los vales del Guadalquivir, el Guadiana y el Tajo en época tartésica. IAM-CSIC. Mérida: 319-36r.

Arruda, A.M., Sousa, E., Pimenta, J., Mendes, H. e Soares, R. (2014): "Alto do Castelo's Iron Age occupation (Alpiarça, Portugal)”. Zephyrus, 74: I43-I55.

Arruda, A.M., Viegas, C. e Almeida, M.J. (coords.) (2002): De Scallabis a Santarém. Museu Nacional de Arqueologia Lisboa.

Aubet, M.E., Carmona, P., Curià, E., Delgado, A., Fernández Cantos, A.e Párraga, M. (1999): Cerro del Villar. I. El asentamiento fenicio en la desembocadura del rio Guadalhorce y su interacción con el binterland. Junta de Andalucía. Sevilla.

Barros, L. e Batalha, L. (2018): "Alguns elementos novos sobre Almaraz". Cira Arqueologia, 6: 50-69.

Barros,L., Cardoso,J.L.e Sabrosa, A. (1993): "Fenícios na margem sul do Tejo. Economia e integração cultural do povoado de Almaraz - Almada. Estudos Orientais, IV: I43-I8I. 
Barros, L. e Henriques, F. (2002): "Almaraz, primeiro espaço urbano em Almada", in $3^{\circ}$ Encontro de Arqueologia Urbana. Actas. Almada: 295-3II.

Barros, L. e Soares, A.M. (2004): "Cronologia absoluta para a ocupação orientalizante da Quinta do Almaraz, no estuário do Tejo (Almada, Portugal)". O Arqueólogo Português, IV-22: 333-352.

Bugalhão, J., Arruda, A.M., Sousa, E. e Duarte, C. (20I3): "Uma necrópole na praia: o cemitério romano do Núcleo Arqueológico da Rua dos Correeiros (Lisboa)". Revista Portuguesa de Arqueologia, 16: 243-275.

Calado, M., Almeida, L., Leitão, V. e Leitão, M. (20I3): "Cronologias absolutas para a Ia Idade do Ferro em Olisipo - o exemplo de uma ocupação em ambiente cársico na actual Rua da Judearia em Alfama”. Cira Arqueologia, 2: II8-I32.

Cardoso, G. e Encarnação, J. (2013): “O povoamento pré-romano de Freiria - Cascais”. Cira Arqueologia, 2: 133 -180.

Cardoso,J.L. (2004): A Baixa Estremadura dos Finais do IV milénio a. C. até à chegada dos romanos: um ensaio de história regional. Oeiras.

Cardoso, J.L., Arruda, A.M., Sousa, E. e Rego, M. (20I4): "Outorela I e Outorela II, dois pequenos sítios da Idade do Ferro a norte do Estuário do Tejo (concelho de Oeiras)". Estudos Arqueológicos de Oeiras, 2I: 393-428.

Cardoso,J.L., Carvalhosa, A.B., Sousa, E., Bugalhão, J.e Sequeira, M.J. (20I7): "Caracterização mineralógica de cerâmica da Idade do Ferro de Lisboa (Núcleo Arqueológico da Rua dos Correeiros)". Revista Portuguesa de Arqueologia, 20: 71-82.

Cardoso, J.L. e Silva, C. T. (2013): "O casal agrícola da Idade do Ferro de Gamelas 3 (Oeiras)". O Arqueólogo Português, V-2: 353-398.

Caro Bellido, A. (1989): Cerámica gris a torno tartesia. Cádis.

Dorado Alejos, A. (2019): Caracterización de las producciones cerámicas de Andalucía Oriental y el Sudeste de la Península Ibérica: del Bronce Tardío al Hierro Antiguo (1550/I50o-550 cal $A C$ ). Tese de doutoramento apresentada à Universidade de Granada.

$<$ https://digibug.ugr.es/handle/I048I/55777>.
González Prats, A. (1983): "La tipología cerámica del horizonte II de Crevillente". Sagvntvm, I4: 6o-96.

González Prats, A., Pina Gosalbez,J.A. (1983): "Análisis de las pastas cerámicas de vasos hechos a torno de la fase orientalizante de Peña Negra (675-550/35 a.C.)". Lucentum, 2: II5-I45.

Groot, B. (201I): Testing Hybridity in Early Iron Age Iberia using ceramics and theory to explain the significance of Phoenician 'colonialism'. Tese de doutoramento apresentada à Faculdade de Arqueologia da Universidade de Leiden. Leiden. Fernandes, L., Pimenta, J., Calado, M. e Filipe, V. (20I3): "Ocupação sidérica na área envolvente do teatro romano de Lisboa: o Pátio do Aljube". Revista Portuguesa de Arqueologia, 16: I67-185.

Filipe, V., Calado, M. e Leitão, M. (20I4): "Evidências orientalizantes na área urbana de Lisboa. O caso dos edifícios na envolvente da Mãe de Água do Chafariz d'El Rei”. Em A.M. Arruda (ed.): Fenícios e Púnicos, por terra e mar. Actas do VI Congresso Internacional de Estudos Fenicios e Púnicos (Lisboa, 2005). UNIARQ. Lisboa: 736-747.

Henriques, S. (2006): A cerâmica cinzenta da Idade do Ferro da Quinta do Almaraz (Almada, Cacilhas). Tese de mestrado apresentada à Faculdade de Letras da Universidade de Lisboa. Lisboa.

Lorrio, A.J. (2008): “Cerámica gris". Em M. Almagro-Gorbea (dir.): La necrópolis de Medellin. II. Estudio de los Hallazgos. Real Academia de la Historia. Madrid: 673-723.

Mancebo, J. (1994): "Las cerámicas grises a torno orientalizantes de la cuenca baja del Guadalquivir”. Em J.M. Campos, J.A. Pérez e F. Gómez (eds.): Arqueología en el entorno del Bajo Guadiana. Actas del Encuentro Internacional de Arqueologia del Suroeste (Huelva, Niebla, I993). Universidad de Huelva. Huelva: 35I-373.

Mayet, F. e Silva,C. T. (2000): Le site phénicien d'Abul (Portugal). Comptoir et sanctuaire. De Boccard. Paris.

Mota, N., Pimenta, J. e Silva, R.B. (20I4): “Acerca da ocupação romana republicana de Olisipo: os dados da intervenção na Rua do Recolhimento n. ${ }^{\circ}$ s 68-70". Cira-Arqueologia, 3: 149-177. 
Mota, N., Pimenta, J. e Silva, R.B. (20I4): "Acerca da ocupação romana republicana de Olisipo: os dados da intervenção na Rua do Recolhimento n. ${ }^{\circ}$ 68-70". Cira-Arqueologia, 3: 149-I77.

Olaio, A. (2018): "O povoado da Quinta do Almaraz (Almada, Portugal) no âmbito da ocupação no Baixo Tejo durante o $\mathrm{I}^{\mathrm{o}}$ milénio a.n.e.: os dados do conjunto anfórico". SPAL, 27 (2): 125-163. <http://dx.doi.org/ro.12795/spal.2018i27.I8>.

Pimenta, J., Calado, M. e Leitão, M. (2005): “Novos dados sobre a ocupação pré-romana da cidade de Lisboa: as ânforas da sondagem n. ${ }^{\circ} 2$ da Rua de São João da Praça”. Revista Portuguesa de Arqueologia, 8 (2): 313-334.

Pimenta, J., Gaspar, A., Gomes, A., Mota, N., Miranda, P. (20I4a): "O estabelecimento romano republicano de Olisipo: estrutura e contextos do Beco do Forno do Castelo, Lote 40 (n. 16-20) Lisboa". Cira Arqueologia, 3: I22-I47.

Pimenta, J., Calado, M. e Leitão, M. (20I4b): "Novos dados sobre a ocupação pré-romana da cidade de Lisboa. A intervenção da Rua de São João da Praça”. Em A.M. Arruda (ed.): Fenícios e Púnicos, por terra e mar. Actas do VI Congresso Internacional de Estudos Feníciose Púnicos (Lisboa, 2005).UNIARQ. Lisboa: 724-735.

Pimenta, J. e Mendes, H. (20IO-20II): "Novos dados sobre a presença fenícia no vale do Tejo. As recentes descobertas na área de Vila Franca de Xira”. Estudos Arqueológicos de Oeiras, 18: 59I-618. Pimenta, J., Mendes, H. e Madeira, F. (2010): “O povoado pré-romano de Castanheira do Ribatejo, Vila Franca de Xira". Revista Portuguesa de Arqueologia, $13:$ 25-56.

Pimenta, J., Sousa, E., Mendes, H., Henriques, E. e Arruda, A.M. (2018): "A Eira da Alorna (A1meirim): as ocupações pré e proto-históricas". Cira Arqueologia, 6: 9-49.

Pimenta, J., Mendes, H., Sousa, E. e Arruda, A.M. (2019): "O sítio de Vale de Tijolos e outros dados acerca da ocupação proto-histórica da margem esquerda do estuário do Tejo". Cira Arqueologia, 7: 6-3I.

Ramon Torres, J., Sáez Espligares, A., Sáez Romero, A. e Muñoz Vicente, A. (2007): El taller alfarero tardoarcaico de Camposoto (San Fernando, Cádiz). Junta de Andalucía. Sevilha.
Rodrigues, M., Pimenta, J., Sousa, E., Mendes, H. e Arruda, A.M. (2019): "A cerâmica cinzenta de Porto do Sabugueiro (Salvaterra de Magos, Portugal)". Cira Arqueologia, 7: 32-58.

Roos, A.M. (1982): "Acerca de la antigua cerámica gris a torno de la Península Ibérica”. Ampuirias 44: 43-70.

Ros Sala, M.M. (1989): Dinámica urbanística y cultura material del Hierro Antiguo en el Valle del Guadalentín. Universidad de Murcia. Murcia.

Sanna, C. (2009): "La cerámica gris orientalizante entre tradición e innovación: el caso de Ronda la Vieja (Acinipo) (Ronda, Málaga). Arqueología $y$ Territorio, 6: 151-164.

Sousa, E. (20I4): A ocupação pré-romana da foz do Estuário do Tejo. UNIARQ. Lisboa.

Sousa, E. (2015): "The Iron Age occupation of Lisbon". Madrider Mitteilungen, 56: 109-г38.

Sousa, E. (2016): "A Idade do Ferro em Lisboa: uma primeira aproximação a um faseamento cronológico e à evolução da cultura material". Cuadernos de Prehistoria y Arqueología de la Universidad Autónoma de Madrid, 42: 167-I85. <http://dx.doi. org/Io.I5366/cupauam20I6.42.006>.

Sousa, E. (2017): "Percorrendo o Baixo Tejo: Regionalização e Identidades Culturais na $2^{\mathrm{a}}$ metade do $\mathrm{I}^{\circ}$ milénio a.C.". Em S. Celestino Pérez e E. Rodríguez González (eds.): Territorios comparados: los vales del Guadalquivir, el Guadiana y el Tajo en época tartésica. IAM-CSIC. Mérida: 295-318.

Sousa, E. (2018): "A tale of two (?) cities: Lisbon and Almaraz at the dawn of the Iron Age". Rivista di Studi Fenici, 46: 137-151.

Sousa, E. e Arruda, A.M. (20I8): "A I Idade do Ferro na Alcáçova de Santarém (Portugal): os resultados da campanha de 200I". Onuba, 6: 57-95.

Sousa, E. e Guerra, S. (2018): "A presença fenícia em Lisboa: novos vestígios descobertos no alto da colina do Castelo de São Jorge". Sagvntvm, 50: 57-88. <http://dx.doi.org/10.7203/ SAGVNTVM.50.10636>.

Sousa, E. e Pimenta, J. (2017): "Produções cerâmicas de inspiração grega no Vale do Baixo Tejo". Arqueologia em Portugal. 20I7-Estado da Questão. Associação dos Arqueólogos Portugueses. Lisboa: $887-896$. 
Sousa, E., Pimenta, J., Mendes, H. e Arruda, A.M. (2016/2017): "A ocupação Proto-Histórica do Alto dos Cacos (Almeirim, Portugal)". Cira Arqueologia, 5: 9-32.

Sousa, E. e Pinto, M. (2016): "A ocupação da Idade do Ferro na colina do Castelo de São Jorge (Lisboa, Portugal): novos dados das escavações realizadas na Rua do Recolhimento/Beco do Leão". Apontamentos de Arqueologia e Património, II: 59-67.

Torres Ortiz, M. (2002): Tartessos. Real Academia de la Historia. Madrid.

Vallejo Sánchez, J.I. (2005): "Las cerámicas grises orientalizantes de la Península Ibérica”. Actas del III Simposio Internacional de Arqueología de Mérida: Protohistoria del Mediterráneo Occidental. IAM-CSIC. Mérida: II49-II72.
Vallejo Sánchez, J.I. (20II): "La punta del iceberg. Reflexiones sobre el proceso productivo de las cerámicas grises orientalizantes de la Península Ibérica (siglos viII-vi a.C.)”. Em J. Abellán, C. Lazarich e V. Castañeda (dirs.): Homenaje al Profesor Antonio Caro Bellido. I. Prehistoria y Protohistoria de Andalucia y Levante. Universidad de Cádiz. Cádis: 36I-377.

Vallejo Sánchez,J.I. (20I5): Las cerámicas grises orientalizantes en la Peninsula Ibérica. Dissertação de doutoramento apresentada à Universidade de Cádis. Cádis.

Vives-Ferrándiz Sánchez, J. (2005): Negociando encuentros. Situaciones coloniales e intercambios en la costa oriental de la Peninsula Ibérica (ss. VIII-VI a.C.). Barcelona. 